\title{
El declinar de la profecía en el siglo II. Notas para un ensayo
}

\author{
Sergio Zañartu, s.j. \\ PONTIFICIA UNIVERSIDAD CATÓLICA DE CHILE
}

\section{E. Aune y algunos estudios}

Después de una introducción que terminará con Jesús como profeta, intentaré esbozar el profetismo de la comunidad cristiana, para finalmente concluir con las principales razones de su declinar. Este sencillo esquema obedece a que en la forma de presentar el surgimiento y desarrollo del profetismo cristiano, ya se van hilvanando diversas causas que contribuirán a su futuro declinar. Pero antes de esto, para comenzar, aludiré muy sucintamente al libro fundamental de D. E. Aune, Prophecy in Early Christianity and the Ancient Mediterranean World. ${ }^{1}$ Reconozco que esta primera entrada en bibliografía trae consigo largas notas con algo de desorden y repetición, pero creo que ayudará a insertar bibliográficamente la presente contribución. Después de los estudios de P. de Labriolle ${ }^{2}$, E. Fascher ${ }^{3}$, G. Friedrich ${ }^{4}$-et alii- en TWNT, Aune ${ }^{5}$ recensiona, como visiones de conjunto sobre la profecía cristiana ${ }^{6}$ en tiempos más recientes, a los siguientes autores: H. A. Guy ${ }^{7}$, al mismo Friedrich en cuanto a la traducción inglesa del diccionario en $1968^{8}$, E. Cothenet ${ }^{9}$, T. M. Crone ${ }^{10}$, y D. Hill ${ }^{11}$. Aunque Aune expone muy sucintamente a estos cinco autores, muestra algunas falencias de ellos que pretende remediar con su propio estudio. Intenta ser más histórico descriptivo, bien contextuado en la historia, pese a la fragmentación de las fuentes ${ }^{12}$. Aune quisiera mostrar una mayor influencia grecorromana en los oráculos cristianos ${ }^{13}$, y comparar estos últimos con lo que se dice acerca de sus profetas y profecía ${ }^{14}$. En su estudio presenta 107 oráculos cristianos ${ }^{15}$. Sus formas ${ }^{16}$ básicas son: oráculos de confianza, de prescripción, de anuncio de salvación, de anuncio de juicio ${ }^{17}$, de legitimación, de teofanía escatológica. A estas se agregan las formas complejas ${ }^{18}$. Si en las narrativas de evangelios y Hch cree este 
autor que algunos oráculos pueden ser literarios y no históricos ${ }^{19}$, eso no lo perturba en su plan, porque igualmente reflejan el sentir de los lectores respecto a lo que entendían como profecía, a lo cual el respectivo oráculo trataría de adaptarse ${ }^{20}$. Pero en su valioso y muy documentado trabajo se centra demasiado, a mi parecer, en las formas de los oráculos y en sus semejanzas o desemejanzas con el A. T., judaísmo primitivo, y medio grecorromano, no percibiendo bien lo referente a los ministerios (y su desarrollo) en la Iglesia primitiva, por ejemplo lo que implica ser apóstol ${ }^{21}$, ni las razones teológicas de fondo. Tampoco desarrolla en profundidad la relación con lo parenético y lo catequético, o la línea de la revelación del misterio, que destaca Col y Ef. No pretendo, en este modesto esbozo ${ }^{22}$, entrar en los numerosísimos datos y su complejidad, sino solo trazar algunas líneas introductorias que sean acordes con las causas del declinar profético, que voy a enumerar. Esta forma de introducirme es una manera de comenzar a decir las causas.

\section{Introducción}

La comunidad de Qumrán tiene la conciencia de estar en el dintel de los últimos tiempos; la comunidad cristiana, en su llegada. Ambas creen tener el Espíritu, aunque de diversa forma. En la comunidad qumránica, el Maestro de Justicia, a quien Dios ha dado el conocimiento de los secretos de las palabras de los profetas, da su interpretación definitiva de ellas, porque los profetas escribieron sin comprender su secreto: ellas eran para los últimos tiempos ${ }^{23}$. Probablemente el Maestro de Justicia, según Aune, ha sido tenido como el nuevo Moisés por los miembros de la secta ${ }^{24}$, pero no es llamado profeta ${ }^{25}$. La profecía judaica había enmudecido, según la creencia de muchos rabinos ${ }^{26}$. Profetas, para Qumran, son los antiguos. Ahora se trata de la reinterpretación definitiva, de un pesher ${ }^{27}$. Esto va con la conciencia y afinamiento del canon del A. T. ${ }^{28}$, que es el fundamento sobre el que se hace la interpretación.

Esto no es demasiado lejano de lo que pasará con el canon del Nuevo Testamento: la época apostólica, que es creativa y con la que concluye la revelación, pasa a ser el fundamento; después viene la época de la interpretación actualizante, de la transmisión viva de la 'tradición apostólica'. Por otra parte, el final de la profecía judía es el comienzo de la apocalíptica ${ }^{29}$; y la apocalíptica, en parte, es una relectura del A. T. ante la inminencia del final. Jesús abrirá el sentido de las Escrituras a sus discípulos ${ }^{30}$. Y Pablo (según Col 1, 25-28; Ef 3, 2ss) proclamará el misterio ${ }^{31}$ de la salvación de 
Dios, oculto desde los siglos y revelado ahora a los apóstoles y profetas: Cristo en vosotros (gentiles). La interpretación, ¿participa de la profecía? Orígenes pensaba que el exégeta también era inspirado ${ }^{32}$. Finalmente, según Flavio Josefo, lo profético no había desaparecido ${ }^{33}$. Algunos esenios, por el mucho conocimiento de la Escritura, podían predecir sin $\operatorname{errar}^{34}$. También el Sumo Sacerdote de vez en cuando profetizaba ${ }^{35}$. Esto último también lo afirma Juan en su evangelio ${ }^{36}$.

En el tiempo de Jesús había expectación por el profeta escatológico ${ }^{37}$ que tenía que venir en los tiempos mesiánicos ${ }^{38}$, $\operatorname{como}_{\text {un Elías }}^{39}$ o un nuevo Moisés ${ }^{40}$. Esto es lo que preguntan a Juan el Bautista ${ }^{41}$, esto es lo que dicen de Jesús ${ }^{42}$. Esto es lo que en parte pretenderían los falsos 'mesías' o profetas ${ }^{43}$, de los que habla Josefo ${ }^{44}$, que prometían signos como volver a dividir las aguas del Jordán ${ }^{45}$. De los profetas se esperaban milagros ${ }^{46}$. Así Jesús va a ser tenido por profeta especialmente por sus milagros ${ }^{47}$. Expresamente pedirán a Jesús que haga un signo para reconocerlo ${ }^{48}$. Pero este responderá con su muerte y resurrección. Era una época de desatada expectativa de liberación, que Aune llama 'milenaria'49. En ese sentido, el profetismo mesiánico estaba a las puertas.

En el contexto, pues, de cierto silencio profético y de expectativa (especialmente para los que no les bastaba con el Templo y la Ley) ${ }^{50}$, surge, en la aurora de los últimos tiempos, la destacada figura de Juan el Bautista $^{51}$, quien es más que un profeta, según Jesús ${ }^{52}$. Juan, que lleva en el desierto la vida de un profeta, anuncia el juicio inminente y al que había de venir, prepara el camino con un gran llamado a la conversión ${ }^{53}$ y un bautismo de penitencia ${ }^{54}$, peculiaridad de su profetismo ${ }^{55}$. Varios de sus discípulos se pasan a Jesús. Muere asesinado por el tetrarca Herodes. Su fuerte repercusión la topamos, años después, hasta en Éfeso ${ }^{56}$. Pero Juan no hizo milagros ${ }^{57}$.

Pero el profeta por excelencia, en el que todo culmina, según la fe neotestamentaria, es Jesús. Si Dios habló en los tiempos antiguos por los profetas, en los últimos tiempos ha hablado por su Hijo (Hb 1, 1s). Según Jn, Jesús es el enviado que nos revela lo que ha oído del Padre ${ }^{58}$. A Dios nadie lo ha visto jamás; es su Hijo unigénito, el que está en su seno, quien nos lo ha revelado ${ }^{59}$. Ver al Hijo es ver al Padre porque el uno está en el otro ${ }^{60}$. Es el Padre quien obra a través de él. Evocando el maná en el desierto y a Moisés ${ }^{61}$, Jesús da el signo de la multiplicación de los panes ${ }^{62}$. La ley fue dada por medio de Moisés, pero la gracia y la verdad vinieron por 
Jesucristo $^{63}$. Según Mt, sentado en el monte promulga la nueva justicia: "Se dijo, yo os digo". En un monte se manifiesta resplandeciente conversando con Moisés y Elías sobre su destino y desde la nube se oye la voz del Padre: 'escuchadlo' (Dt 18, 15) ${ }^{64}$. Siguiendo otra línea, el Espíritu de Dios está sobre É $1^{65}$. Ha sido enviado ${ }^{66}$ a evangelizar a los pobres, a proclamar la liberación de los cautivos, la vista a los ciegos, un año de acogida por el Señor ${ }^{67}$. Ungido por el Espíritu en su bautismo para su misión, lo posee en plenitud ${ }^{68}$ y lo dará en su glorificación a sus discípulos, que serán sus testigos ${ }^{69}$. Conoce el interior de las personas ${ }^{70}$; como el más fuerte expulsa a los demonios ${ }^{71}$; perdona los pecados y hace milagros: los ciegos ven, los sordos oyen, los muertos resucitan y los pobres son evangelizados ${ }^{72}$. Llama a la conversión y anuncia la llegada del reinado de Dios, su Abba.

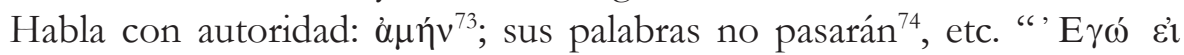
$\mu \mathrm{l}$ ” oímos en Jn. Así se expresa Friedrich: "Jesús como profeta no es justamente un portavoz de Dios que tenga que introducir su predicación

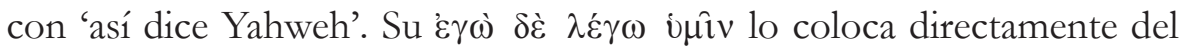
lado de Dios" ${ }^{75}$. Tiene oráculos de futuro ${ }^{76}$. Es muerto en Jerusalén, como los profetas ${ }^{77}$. Los discípulos en la resurrección lo proclaman 'Señor'. Y

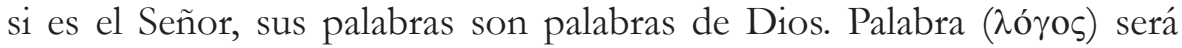
llamado en el prólogo de Jn. Es obvio que estas afirmaciones sobre Jesús, que van entrelazadas con lo histórico y son obra del Espíritu que conduce a toda verdad ${ }^{78}$ respecto a lo de Jesús, reflejan la fe de los discípulos, pero esto es lo que más interesa en este trabajo. ${ }^{79}$ Porque es esta la percepción, al menos implícita, que los cristianos primitivos, que proclamaban a Jesús como Señor, tenían de Él como 'profeta'; y a su sombra y en relación a ella se recortarán las pequeñas figuras de los profetas cristianos, de los que trataré. Ciertamente el pueblo lo tuvo por profeta ${ }^{80}$.

$\mathrm{Al}$ respecto expresa Aune en un enfoque más histórico: “El estatus profético de Jesús, desde su propia perspectiva, como desde la de muchos de sus contemporáneos, estaba basado en su proclamación de la llegada inminente del reino de Dios y en los milagros que realizó como modo de legitimación de esta proclamación. Los diversos dichos de Jesús que tienen la forma de predicción del futuro, ya conciernan éstos a la destrucción del templo, a anuncios del juicio que viene, a la venida del Hijo del hombre, o a su propia muerte y victoria final, todos ellos se relacionan, en forma fundamental, a su proclamación de la llegada inminente del reino de Dios" $"$. Pero el título 'profeta' no prosperó en la comunidad cristiana, quizás por quedarse corto ${ }^{82}$ ante el título de Hijo (unigénito) de $\mathrm{Dios}^{83}$. 
Originalidad del profetismo de Jesús fue tener apóstoles con los que compartió su misión y sus signos, como hacer milagros en su nombre ${ }^{84}$. Finalmente, comunicando el Espíritu, Jesús será la fuente de esa sabiduría sobrenatural que volverá eficaz el testimonio de los apóstoles ${ }^{85}$.

\section{Esbozo del profetismo en la Comunidad Cristiana}

Con la resurrección de Jesús se produce la gran efusión del Espíritu a todo el nuevo pueblo ${ }^{86}$, Espíritu que puede ser comunicado por la imposición de manos de los apóstoles ${ }^{87}$. Con todo, el Espíritu es libre para irrumpir en lo de Cornelio. Ahora, en los últimos días, según Joel todos profetizarían $^{88}$. Pero más que esto, todos son agraciados con diversos carismas del Espíritu para edificación del cuerpo ${ }^{89}$. Porque no todos son 'profetas ${ }^{900}$, aunque Pablo desee este carisma para todos ${ }^{91} .1$ Ts 5, 19ss, según Cothenet, parece ligado a la espera escatológica. Probablemente profetas, que en la reunión litúrgica clamarían maranatha, habían dado pie a que algunos creyeran que el día del Señor llegó ${ }^{92}$. Solo en el Espíritu se proclama: Jesús es Señor ${ }^{93}$. Según $\mathrm{Hch}^{94}$, el Espíritu conduce a la Iglesia en la misión ${ }^{95}$ y sus mensajes son a menudo mediante los llamados profetas. Así se destina a Pablo y Bernabé para la misión ${ }^{96}$, y anuncia a Pablo las penalidades que le esperan en Jerusalén ${ }^{97}$. La decisión del concilio de Jerusalén es decisión del Espíritu ${ }^{98}$. Entre los llamados profetas ${ }^{99}$, destaca Ágabo con su profecía simbólica (esto dice el Espíritu Santo ${ }^{100}$ ) y con su anuncio de la próxima hambruna ${ }^{101}$. A Timoteo los presbíteros le imponen las manos por intervención profética ${ }^{102}$. La comunidad cristiana de Jerusalén, según Eusebio y Epifanio ${ }^{103}$, se trasladará a Transjordania durante la guerra judía, advertida por una profecía ${ }^{104}$.

Los corintios están demasiado obnubilados con la glosolalia ${ }^{105}$, que Pablo distingue de la profecía. El que habla lenguas, habla solo a Dios (salvo que alguien lo interprete); el profeta ${ }^{106}$, en cambio, habla a los hombres con palabras inteligibles y así edifica a la Iglesia ${ }^{107}$. Propio de él es exhortar y dar ánimo, edificar la Iglesia ${ }^{108}$; también penetra los secretos del corazón ${ }^{109}$. Los profetas reciben revelaciones ${ }^{110}$. Que haya orden ${ }^{111}$. Porque el Espíritu de los profetas está sometido a los profetas ${ }^{112}$. Que no profeticen las mujeres en la asamblea y que se cubran el cabello ${ }^{113}$. Los profetas de 1 Co están sometidos al discernimiento de la comunidad ${ }^{114}$. El apóstol, sin embargo, no aparece sometido a la comunidad. Pablo exige que los profetas o $\pi v \varepsilon v \mu \alpha \tau \iota \alpha^{\prime 115}$ reconozcan que lo que él escribe es una orden del Señor ${ }^{116}$. Pablo prefería la profecía por sobre los otros 
carismas $^{117}$. Los profetas, como puestos por Dios, vienen en segundo lugar después de los apóstoles ${ }^{118}$.

Si los profetas en 1Co son varios y actúan en la entusiasta reunión comunitaria ${ }^{119}$, según la Didaché debe dárseles libertad para la acción de gracias $^{120}$. Pueden tener iniciativas a favor de los pobres. El profeta una vez discernido, hay que respetarlo ${ }^{121}$ para no pecar contra el Espíritu ${ }^{122}$. Hasta puede representar el misterio cósmico de la Iglesia, con tal que no enseñen esto a otros ${ }^{123}$. Los profetas reciben de los cristianos las primicias de todo ${ }^{124}$. Pero es hora de elegir obispos y diáconos ${ }^{125}$. Las comunidades pueden no tener profeta ${ }^{126}$. En Mt, que reflejaría también un medio siríaco, se habla de acoger a un profeta en tanto profeta ${ }^{127} \mathrm{y}$ de haber profetizado en el nombre del Señor ${ }^{128}$.

Pablo, que no se llama a sí mismo profeta sino apóstol, también tiene los rasgos de un gran profeta ${ }^{129}$, comenzando por su vocación ${ }^{130}$. El resucitado se le reveló bruscamente en el camino a Damasco ${ }^{131}$ y le envía a Ananías para que lo bautice. Es un instrumento de elección para llevar el evangelio a los paganos ${ }^{132}$. Vence al mago judío Elimas ${ }^{133}$ anunciándole su inmediata ceguera. Su predicación va acompañada por el poder del Espíritu $^{134}$. Realiza curaciones milagrosas ${ }^{135}$. Ha recibido el Espíritu que viene de Dios y habla lo espiritual en términos espirituales ${ }^{136}$. En un rapto es llevado al tercer cielo ${ }^{137}$. En Corinto y en Jerusalén tiene visiones ${ }^{138}$. Anima a los marineros con una visión angélica, y les promete que todos se salvarán, excepto el barco ${ }^{139}$. Es tenazmente perseguido y termina mártir. A él se le ha encargado anunciar a los gentiles el misterio del plan de Dios, del cual tiene un gran conocimiento ${ }^{140}$.

De Pedro, quien no se deja engañar por Ananías ${ }^{141}$ y Zafira, podríamos decir otro tanto ${ }^{142}$. El fondo es que los apóstoles también son profetas. No solo por estos signos, sino principalmente porque, enviados por el Señor y bautizados en el Espíritu, anuncian a Jesús como Señor y transmiten su revelación ${ }^{143}$. Y en Jesús, el Hijo, había culminado la profecía, la revelación. Por eso el texto de Ef 2, 20 afirmaría, según Cothenet, que, siendo Jesucristo la piedra angular, el fundamento de la Iglesia son los apóstoles, que son profetas ${ }^{144}$. Se utilizaría de una endiadis en este texto y por eso se antepone una sola vez el artículo: para apóstoles y profetas. Ser apóstol engloba el ser profetas ${ }^{145}$; ellos constituyen y consolidan en el Espíritu la tradición apostólica, transmitiendo así la revelación de Dios en Cristo. Y esto es de máximo interés. Así, en cierto sentido, substituyen 
a los profetas del A. T. ${ }^{146}$. Pero esta misma realidad, que por su dinámica desembocará en los obispos (con su prebiterio) como sucesores de los apóstoles, terminará por arrinconar y marginalizar el rol de los llamados 'profetas' en las primeras comunidades. Y, siguiendo la tendencia del judaísmo y de acuerdo con la apólogética cristiana que ve en el A. T. una gran profecía sobre Cristo y la Iglesia, 'profeta' quedará reservado muy principalmente para los del A. T. ${ }^{147}$. Por su parte y en mayor medida, los doce (y Pablo) marginalizarán a otros que también fueron llamados 'apóstoles', cuya itinerancia aparecía en $\mathrm{Did}^{148}$.

Central va a ser, pues, la tradición apostólica, que por inspiración del Espíritu ${ }^{149}$ se decantará en los escritos del Nuevo Testamento, los cuales irán siendo recibidos como canónicos por la fe de los cristianos, pueblo profético que reconoce en esos escritos, bajo la acción del mismo Espíritu, lo originario de Cristo y su Iglesia: la revelación de Dios. ¿Cómo colaboraron los llamados 'profetas' en la tradición apostólica? Ciertamente con sus exhortaciones sobre el modo de ser cristiano, pero según Aune, no consta que hayan tenido una especial colaboración ni en la creación de los dichos de Jesús ni en su transmisión ${ }^{150}$. Obviamente que hubo una gran actividad de interpretación y aplicación del A. T. a Cristo y su Iglesia para poder expresar el misterio cristiano ${ }^{151}$; Aune la llama exégesis carismática ${ }^{152}$. Pero este autor, que por lo demás margina a los apóstoles, sitúa esta labor como propia de los doctores ${ }^{153}$. E. Cothenet,

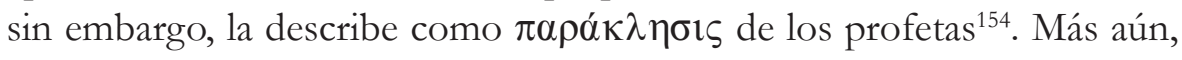
cuando se desataron serios problemas doctrinales, no parece que los llamados 'profetas' con el contenido de sus profecías hayan jugado un papel determinante a favor o en contra. Es verdad, que los herejes pueden ser llamados pseudoprofetas ${ }^{155}$, pero este término negativo, que viene del A. T., pareciera tener una mayor amplitud que la simplemente contraria al profeta neotestamentario, porque incluye y caracteriza también a falsos doctores ${ }^{156}$, falsos apóstoles ${ }^{157}$, falsos cristos ${ }^{158}$, etc. ${ }^{159}$. Justamente en Did y Herm, donde hay contraposición directa de los pseudoprofetas con los los profetas de la comunidad, no se alude a herejías presentes en las que estos últimos intervengan ${ }^{160}$. Era más bien oficio de los doctores explicar la tradición apostólica ${ }^{161}$, que será garantizada y defendida apasionadamente por la jerarquía. Contra los herejes, Ireneo y Tertuliano recurrirán a la tradición de las Iglesias apostólicas. Con todo, la progresiva constitución del canon neotestamentario debe haber contribuido a la marginación de las palabras de los profetas de la comunidad, que casi no se conservan. 
Pero hay una brillante y notable excepción, el Ap, el cual finalmente quedó dentro del canon.

El escrito del N. T. con fuerte hálito profético, es el Apocalipsis ${ }^{162}$, aunque sea una mezcla de profecía y apocalíptica ${ }^{163}$. El lector se ve como enfrentado, directamente y con mucha fuerza, a la palabra y revelación de Dios. Si se lo compara con las revelaciones del Pastor (o la mujer-Iglesia) a Hermas, este último da la impresión de una profecía desvigorizada, demasiado apocalíptica literaria con una fuerte insistencia moral, aunque pueda haber un núcleo de experiencia originaria en las visiones de Hermas $^{164}$. Por lo demás, Hermas nunca se llama a sí mismo 'profeta'165. $\mathrm{El}$ autor del Ap no se esconde debajo de la pseudonimia. Se trata de una profecía ${ }^{166}$; sus hermanos son los profetas. ${ }^{167}$ Como profeta come un librito para profetizar ${ }^{168}$. En el día del Señor, Juan es tomado por el Espíritu $(\varepsilon \gamma \varepsilon v o ́ \mu \eta v \dot{\varepsilon} v \pi v \varepsilon v ́ \mu \alpha \tau \iota)^{169}$. Recibe la orden de escribir ${ }^{170}$ el mensaje del resucitado para cada una de las siete Iglesias ${ }^{171}$ en una imponente visión en que este aparece con vestidura sacerdotal. El mensaje ${ }^{172}$ es perentorio: El que tenga oídos, oiga lo que el Espíritu dice a las Iglesias ${ }^{173}$. Pero todo el Ap es un mensaje ${ }^{174}$ en que se suceden las visiones ${ }^{175}$. Según Cothenet, el testimonio es el de Jesús, el resucitado ${ }^{176}$. Según 19, 10, el testimonio de Jesús ${ }^{177}$ es el espíritu de la profecía ${ }^{178}$. Los dos testigos invulnerables ${ }^{179}$ que profetizan, representarían la función profética de la Iglesia a lo largo de los siglos ${ }^{180}$. Tienen que morir como su Señor, pero, después de tres días y medio, se ponen de pie y suben en la nube al cielo. Babilonia cae. La bestia, y el pseudoprofeta, que hace milagros y engaña a muchos, y el diablo ${ }^{181}$, son derrotados por el Rey de reyes y Señor de señores, y lanzados al estanque de fuego y azufre. Es Dios que interviene para el gran juicio ${ }^{182}$. Desciende la Jerusalén celestial como novia para el cordero. Termina con graves amenazas al que añada o quite algo de la profecía de este libro ${ }^{183}$. Es un mensaje sobre los últimos tiempos ya comenzados y su inminente final, que contextúa en una gran lucha el testimonio de Jesús, y fortalece la espera. En cuanto la autoridad ilimitada del Ap, afirma Friedrich: "El Apocalipsis es lo más cercano en este sentido a la profecía judía. Aquí de ninguna manera puede ser cuestión de probar la validez de los dichos, porque ellos son legitimados como seguros y verdaderos por la suprema autoridad, el mismo Dios (Ap 21,5; 22, 6)"184.

1 Co 14, 15, Ef 5, 19 y Col 3, 16 hablan de himnos inspirados ${ }^{185}$, cuya recitación florecería en las liturgias. Pero estos, en general, no se conservan. Algo se vislumbra por Flp 2, 6ss, Ef 1, 3ss, Col 1, 15ss., Jn 1, 
1ss, sin olvidar los de la infancia de Jesús en Lc, etc. En el Ap aparecen himnos litúrgicos ${ }^{186}$, pero no habría base suficiente para atribuirles un origen profético ${ }^{187}$. Las Odas de Salomón son una colección de hermosos himnos cristianos, probablemente de Siria oriental, que datarían del s. II. Dentro de una mística (en general personal) con variadas referencias a Cristo muestran una profunda conciencia de inspiración. Por ejemplo, es el Espíritu quien canta en los hombres las alabanzas de Dios ${ }^{188}$. Contienen una serie de pasajes en que, al parecer, es Cristo el que habla ${ }^{189}$. Según 32, 1s, el Señor habita en el corazón del salvado y de él fluyen las palabras de la verdad. Según 42, 6, el resucitado hablará a través de la boca de los que lo buscan. En 10, 1-3, donde se habla como de un ministerio respecto a los demás, tenemos quizás lo más parecido a una función profética ${ }^{190}$, pero que no es llamada así. En 36, 1s, el odista describe un viaje al cielo, donde continúa componiendo himnos y glorificando a Dios ${ }^{191}$. Concluye Aune su análisis de las Odas afirmando: "Aunque las odas no entreguen con facilidad sus secretos, parece que ellas son mejor consideradas vistas como un tipo distintivo de himnario profético, que, manteniendo conexión con otros tipos de discursos proféticos cristianos, permanecen, sin embargo, únicas" ${ }^{\prime 192}$.

Al comienzo del s. II tenemos el hecho profético de Ignacio de Antioquía en Filadelfia, quien, no por conocimiento humano sino porque el Espíritu, que revela los secretos y no se deja engañar, se lo anunció, clamó con gran voz, voz de Dios, que se adhirieran a la jerarquía, etc. ${ }^{193}$. Pero Ignacio, que tiene la autoridad del carismático, sobre todo del mártir ${ }^{194}$, que conoce lo celestial ${ }^{195}$, que puede tener una revelación sobre la comunidad de Éfeso ${ }^{196}$, que confía en que Cristo revelará a los romanos la verdad de lo que dice ${ }^{197}$, que se autollama $\Theta \varepsilon$ có́pos, que siente en su interior un agua viva que lo llama hacia el Padre ${ }^{198}$, no habla de profetas del N. T., ni se atribuye a sí mismo ese título. Más bien su jerarquía (obispo, presbiterio y diáconos) no deja mucha cabida para un profeta itinerante. Policarpo será llamado maestro profético ${ }^{199}$. Si en el Nuevo Testamento nos encontramos con no pocos 'profetas' individuales, en el s. II éstos escasean. Cuando en el tercer cuarto de este siglo la profecía montanista remezca la Iglesia, esta, que ha permanecido con la conciencia de tener el carisma de profecía ${ }^{200}$, solo atina a enumerar a los del N. T., más Ammia de Filadelfia y Cuadrato ${ }^{201}$. En este sentido, la profecía ha declinado. Según G. Friedrich, "el montanismo fue el último gran fulgor de la profecía en la Iglesia" 202 . 
Según C. Trevett, si en los años 70 del s. II se dio la confrontación con el montanismo, este habría surgido por los años 60, en tiempos calamitosos y en Iglesias que ya tenían semillas proféticas ${ }^{203}$. Es un reavivamiento frente a una Iglesia cada vez más estructurada y centrada en la tradición apostólica en su lucha contra el gnosticismo ${ }^{204}$. Según $\mathrm{Hill}^{205}$, es la época de la dispensación del Espíritu. Montano es la boca del Paráclito. La venida del Paráclito es un preludio inmediato a la venida de Cristo y el establecimiento de la nueva Jerusalén en Pepuza ${ }^{206}$. El entusiasmo carismático va acompañado de una moral rigurosa que colinda en el dualismo. El montanismo presenta rasgos del fanatismo de los cultos asiáticos. Este movimiento se convierte en secta que termina repudiando a la jerarquía de la Iglesia, etc. ¿Por qué la Iglesia rechazó el profetismo montanista? Porque no condecía con la práctica que ella había tenido, es decir, con los profetas de las comunidades. Los profetas del N. T. estaban sometidos a la comunidad, y los montanistas no se sometían a la jerarquía ${ }^{207}$, ni aceptaban que Maximilla fuera exorcizada ${ }^{208}$. Profetizaban en éxtasis ${ }^{209}(\pi \alpha \rho \varepsilon ́ \kappa \sigma \tau \alpha \sigma \iota \varsigma)$, contra el dicho paulino que el espíritu de los profetas está sometido a éstos ${ }^{210}$; anunciaban un inminente descenso de la Jerusalén celestial ${ }^{211}$, etc. ${ }^{212}$. Una pregunta quizás de fondo: ¿Tenían los montanistas, en su profecía absoluta al margen de la tradición de las Iglesias, plena conciencia de que la revelación había ya terminado en Jesucristo y su correspondiente época apostólica? ${ }^{213}$. Según Trevett, el problema estaba sobre todo en la autoridad con que intervenían los profetas montanistas en una Iglesia ya organizada en torno a lo apostólico y la jerarquía. ${ }^{214}$ Pero la crisis montanista ha puesto al descubierto el declinar de los profetas en la gran Iglesia. Con todo, la carismática es bastante más amplia que el círculo de profetas de la comunidad y va evolucionando según las circunstancias. Cothenet piensa que los 'confesores', algunos de los cuales por lo demás tienen visiones ${ }^{215}$, pasan a ocupar el centro carismático de la Iglesia ${ }^{216}$. Agustín joven, en De vera religione ${ }^{217}$, pensaba que la carismática de los primeros tiempos ya no se necesitaba, porque se había consolidado la fe cristiana ${ }^{218}$. Por otro lado, la Iglesia continúa su perenne función profética anunciando a Jesucristo.

Hay un tema que me falta tocar antes de presentar las razones del declinar de la profecía, y es el de su discernimiento ${ }^{219}$. El discernimiento puede ser complicado y volver poco práctico el uso de la profecía en la comunidad $^{220}$. Para Dt 18, $20^{221}$ es falso profeta el que hable en nombre de otros dioses, para las cartas de Juan el que no confiese que Cristo vino 
en carne ${ }^{222}$, para Pablo sería el que llegare a decir anatema sea Jesús ${ }^{223}$. Se trata de un criterio doctrinal ${ }^{224}$. Para el Dt 18, 22 es también falso si no se cumple lo que profetizó 225 ; igualmente para Jeremías cuando se trata de una profecía de paz, porque los verdaderos profetas han solido anunciar el infortunio ${ }^{226}$. Pero a veces es difícil verificar los cumplimientos proféticos, porque generalmente no son diáfanas las profecías y sus cumplimientos, o éstos se van realizando poco a poco o demoran ${ }^{227}$. Jesús da la norma clave de todo discernimiento: por sus frutos los conoceréis ${ }^{228}$. Pablo habla de probar $(\delta о \kappa \imath \mu \alpha ́ \zeta \varepsilon \tau \varepsilon)$ todo y de retener lo bueno ${ }^{229}$. Enumera un carisma de discernimiento de espíritus ${ }^{230}$. Así la comunidad profética discierne al profeta que habla ${ }^{231}$. La Didaché232 afirma que no todo el que habla en espíritu es verdadero profeta. Hay que probarlo; y una vez

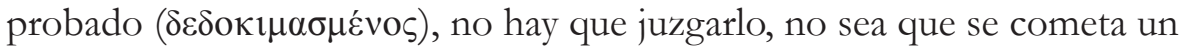
pecado irremisible. Lo clave es que tenga las maneras del Señor. Tiene que practicar la verdad que dice. No debe buscar su propio provecho. Si ordena una mesa, que él no coma de ella. Hablando en espíritu no debe pedir dinero u otros dones. Hermas, en el Mandamiento $\mathrm{XI}^{233}$, dice que el verdadero profeta no habla por ser consultado sino cuando Dios quiere ${ }^{234}$, y habla delante de la comunidad y no en los rincones, dando

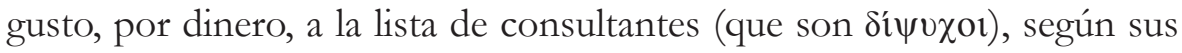
concupiscencias $^{235}$. El verdadero profeta es dulce, modesto, etc. ${ }^{236}$. Pero además del modo de proceder, presenta un criterio, por así llamarlo, de confrontación carismática ${ }^{237}$. El verdadero profeta, que tiene el Espíritu de Dios, habla ante la asamblea de los justos que suplican a Dios; el falso enmudece, permanece vacío ${ }^{238}$. Su espíritu es terrestre, sin fuerza. 1Jn 2, 20.27, a propósito de los engaños, nos recuerda que hemos recibido la unción, que nos enseña y que es verdadera. Relatos de la vocación del profeta servirían en el A. T. para autentificar su profecía ${ }^{239}$. Aune concluye que no hay un criterio definitivo ${ }^{240}$. Parece que el medio ascético judío ofrecía más elementos para un buen discernimiento, que la cultura retórica y racional grecorromana. Quizás este trasplante cultural influyó ${ }^{241}$ en una menor utilidad del profetismo.

\section{Principales razones del declinar profético}

Habiendo presentado algunas líneas del despliegue de la profecía cristiana que nos ayuden a entender su declinar, pasemos ahora a enumerar las razones que creo que más influyeron en esto ${ }^{242}$. La primera y principal es que la revelación culminó en Cristo Jesús definitivamente ${ }^{243}$. Habiendo 
Dios hablado por los profetas, en los últimos tiempos (ya no hay un otro tiempo) habló por su Hijo, que es su Palabra. Por así decirlo, ya no quedan más palabras, no hay una otra palabra. Dios se autorreveló. Lo definitivo ha llegado. Lo que interesa ahora es recibir el mensaje del Hijo. De ahí la importancia de los apóstoles y de su tradición, que nos lo transmiten ${ }^{244}$. A esto se añade que con la era apostólica termina de ponerse el fundamento de la Iglesia ${ }^{245}$ y se entra de lleno en la interpretación y aplicación de lo ya dado, a cargo sobre todo de pastores y doctores. Más aún, por el discernimiento de la Iglesia, los escritos del Nuevo Testamento pasan a ser considerados canon inspirado y cerrado. Conforme a todo esto, ya en la era apostólica, el papel de los llamados profetas era secundario y estaba subordinado a la comunidad ${ }^{246}$ y a la autoridad apostólica. En esto se percibe una gran diferencia con los profetas del Antiguo Testamento ${ }^{247}$, los cuales más bien son sucedidos por los apóstoles. Y 'profeta' tiende a reservarse para los del A. T., siguiendo al judaísmo y en controversia con él. El cumplimiento del vaticinio profético en Cristo y la Iglesia, era gran argumento apologético.

Dicho de otra forma, con la efusión del Espíritu y sus carismas, también encontramos 'profetas', apreciados por Pablo, etc., pero cuyo marco de acción parece ser más restringido que el de los del A. T. ${ }^{248}$, porque lo fundamental va por la línea apostólica y la expresión de la fe en Cristo, que decanta en los escritos inspirados del N. T. Detrás de todo esto está la acción del Paráclito que comunica lo de Cristo y conduce a toda verdad ${ }^{249}$. 'Profetas', pues, eran llamados en la comunidad los que profetizaban en forma más regular. En la visión de Cothenet, profetas fueron primeramente los apóstoles, fundamento de la Iglesia (Ef 2, 20). Y todo el Nuevo Testamento es revelación de Dios, inspirado por el Espíritu (cf. 2 Tm 3, 16), según el discernimiento de la misma Iglesia. Muy excepcional es el Ap donde la apocalíptica va junto con la frescura de la profecía, esta vez sobre los designios de Dios salvador en la historia que finaliza. El Ap en su esplendor hace palidecer, en cuanto profecía, la otra apocalíptica cristiana que se producirá, p. e. el Pastor de Hermas. Si en el Ap culmina, en cierto sentido, la revelación del misterio mantenido oculto durante siglos y revelado en Cristo, quizás se podría decir que en las Odas de Salomón culmina, no ya la revelación, sino la personalización mística de los himnos cristianos en esa época. El enfriamiento en la espera de una pronta parusía del Señor, contribuirá a que ya no se produzcan nuevos apocalipsis como el de Juan ${ }^{250}$. El problema del montanismo es que estuvo fuera de tiempo y de tiesto. Generó una fuerte polémica y terminó 
contribuyendo al descrédito de los profetas de la comunidad ${ }^{251}$. Si Juan Bautista, Jesús, Ap y montanismo fueron profetas de los últimos tiempos, el llamado 'retraso de la parusía', la disminución de la conciencia (tensión) escatológica, tiende a descolocar nuevas manifestaciones del profetismo escatológico ${ }^{252}$, y para la marcha ordinaria de la Iglesia muestran mayor utilidad los pastores y la tradición apostólica, la que cristaliza en los escritos inspirados del N. T.

El auge o declinar del profeta del N. T., dentro de sus limitaciones, está obviamente marcado por la iniciativa de Dios, quien habla cuando quiere, lo que constituye una gran diferencia con los adivinos y los centros de oráculos grecorromanos, los que parecen irrumpir en el falso profeta de Hermas. También depende de que la comunidad y los cristianos tengan el oído atento para escuchar y sepan y puedan discernir, lo que no es fácil. En los reavivamientos carismáticos de los cristianos en el Espíritu se vuelven a producir profecías en la oración y una cierta glosolalia, pero terminan chocando con el problema central de su utilidad: la edificación de la Iglesia como diría Pablo, la contribución a la caridad ${ }^{253}$. En el s. II, la profecía cristiana no fue muy útil en los grandes problemas que tuvo que enfrentar la Iglesia. De parte del hombre, en la utilidad se juega quizás el auge o declinar de los 'profetas'. Pero el discernir la voluntad de Dios, sigue siendo fundamental para el cristiano y la Iglesia, y se ha ejercitado en todos los tiempos. En el declinar también influyó la implantación de la fe en la cultura grecorromana. Aunque en esta hubo una alta demanda de oráculos para asegurar el futuro de ciudades e individuos, ella era predominantemente racional, retórica y legal (según el genio del Imperio). Su profetismo era de bajo nivel en comparación con el del judeocristiano y su respectiva revelación ${ }^{254}$. La primitiva profecía cristiana y su discernimiento se había desplegado en otro 'humus', que no era el grecorromano. Estas, pues, serían razones principales, a mi modo de ver, del declinar de la profecía cristiana en el s. II, sin olvidar la creciente organización de la Iglesia ${ }^{255}$. El montanismo terminó mostrando los inconvenientes de la profecía en la vida de la Iglesia. Según J. L. Ash y en contra la hipóstesis de Harnack, el episcopado monárquico se apropia el carisma de profecía y terminará volviéndolo superfluo ${ }^{256}$. Schöllgen destacará como causa del ocaso del profetismo de los 'profetas' itinerantes cristianos y paganos, el propio fracaso en su credibilidad ${ }^{257}$. Pero el declinar de los 'profetas' no fue el declinar de la función profética de la Iglesia, que le es esencial, ni de los carismas que van variando según circunstancias y necesidades ${ }^{258}$. 
Mi visión de las causas del declinar de los profetas difiere de la de Aune, quien destaca más lo social que lo teológico. Grosso modo, según él la profecía dejó de ser útil, siendo desplazada por la creciente institucionalización de la Iglesia y la racionalización de las estructuras de autoridad ${ }^{259}$. No es que no haya habido algo de esto, pero Aune no dio la importancia debida al oficio de apóstol de una revelación que culmina en Cristo, y a la correspondiente tradición apostólica. Tampoco valoró que la voluntad concreta de Dios la Iglesia y los cristianos no la encuentran por una simple racionalización e institucionalización. La Iglesia ha seguido siendo 'profética' y discerniendo la voluntad de su Señor (aunque a ratos con diversas desviaciones). Y el carisma ha permanecido vivo, aunque se haya manifestado en otras formas, y no mediante los llamados 'profetas' de la comunidad. Quizás el problema del Montanismo fue no haber percibido que el fundamento de la Iglesia ya estaba puesto y que la función profética en la Iglesia era de otro tipo.

Finalmente, algún lector puede objetar este trabajo por su punto de vista demasiado subjetivo o de $\mathrm{fe}^{260}$. Pero considere que se trata de un ensayo.

\section{Resumen}

El autor presenta recientes estudios sobre el tema, como el de Aune. Introduce con Qumrán, Juan Bautista y Jesús, siendo este la Palabra definitiva de Dios. En su esbozo recorre diversas fuentes en el siguiente orden. Irrupción del Espíritu y Hch. La profecía en Corinto y en la Didache. Pablo y Pedro como profetas. Tradición apostólica, dichos de Jesús y exégesis carismática. No especiales problemas doctrinales en el profetismo. La profecía de Ap y su autoridad. Los himnos inspirados, como las Odas de Salomón. Ignacio de Antioquía y Policarpo. El desafío del montanismo y el discernimiento de la profecía. Orientado por este recorrido, el autor concluye presentando las principales razones del declinar profético.

\section{Palabras clave}

Profecía neotestamentaria, Profecía en siglo II, Discernimiento profético, Montanismo. 


\section{Summary}

The author presents recent studies on the subject, such as that of Aune. He begins with Qumran, John the Baptist and Jesus, He being the definitive word of God. In his study, he goes through various sources in the following order. Emergence of the Spirit and Acts; the prophecy in Corinth and the Didache. Paul and Peter as prophets. Apostolic tradition, quotes of Jesus and charismatic exegesis. Non special doctrinal issues in the prophetism. The prophecy of the Revelation and its authority. The inspired hymns such as Solomon's Odes. Ignatius of Antioch and Polycarp. The challenge of Montanism and the discernment of the prophecy. Following this course, the author concludes by presenting the main reasons of the prophetic decline.

\section{Key Words}

Neotestamentarian Prophecy, Prophecy in $2^{\text {nd }}$ century, Prophetic Discernment, Montanism.

\section{Notas}

1 Grand Rapids (Michigan), 1983. Otras publicaciones irán apareciendo en las notas a lo largo de mi trabajo.

2 Les sources de l'bistoire du Montanisme (Collectanea Friburgensia), 1913. Idem, La crise montaniste, Paris 1913.

3 ПРОФНТН . Eine sprach- und religionsgeschichtliche Untersuchung, Giessen 1927.

4 Propheten und prophezeien im Neuen Testament, TWNT, VI, 829-858. Idem, Propheten in der alten Kirche, TWNT, VI, 858-863.

5 Prophecy, 1-14.

6 Según Friedrich, "Primitive Christian prophecy is the inspired speech of charismatic preachers through whom God's plan of salvation for the world and the community and His will for the life of individual Christians are made known" (p. 848, en Aune, Prophecy, 5, corresponde a p. 849 de TWNT VI). Según el mismo Friedrich (TWNT VI, 857), "Der Prophet ist der geistbegabte Seelsorger der Gemeinde, der ihr ganz konkret sagt, was sie in der gegenwärtigen Situation zu tun hat, der tadelt und lobt, dessen Verkündigung Ermahnung und Trost, Busswort und Verheissung enthält (1 K 14, 3)". M. Boring define así al profeta cristiano: "The early christian prophet was an immediately-inspired spokesperson for God, the risen Jesus, or the Spirit who received intelligible oracles that he or she felt impelled to deliver to the christian community or, representing the community, to the general public" (Prophecy. Early Christian Prophecy, Anchor Bible Dict., V, 495-502, p. 496; cf. Idem, The Continuing Voice of Jesus. Christian Prophecy and the Gospel Tradition, Louisville, Kentucky, 1991, pp. 3545). En contra de esto encontramos un exceso en J. Panagopoulos (Die urchristliche Prophetie: Ihr Charakter und ihre Funktion, en J. Panagopoulos, Prophetic Vocation in the 
New Testament and Today (Supplements to Novum Testamentum, 45), Leiden 1977, 1-32, p. 32), quien declara: "wir haben Prophetie als Funktion der Kirche aufgefasst", extendiendo el concepto a la amplia función profética de la Iglesia. Es el don del Espíritu a la comunidad escatológica $(I b ., 7)$. "Prophetisch ist ja die neu geschaffene Existenz aller Gläubigen” (Ib., 10).

7 New Testament Prophecy: Its Origin and Significance, London 1947. Según Aune, Guy dedica solo 29 pp. al profetismo de la Iglesia del s. I, porque está centrado en Jesús de Nazaret, culminación de la profecía, culminación que no podrá volver a ser alcanzada. "In effect the book is a statement of faith in which theologically laden concerns and presupposition are lightly seasoned with a mild strain of historical criticism" (Prophecy, 1s). Su argumentación es dispareja. "In discussing prophetism in the first-century church, the author moves quickly and superficially through Acts and the Corinthian situation" (Prophecy, 3). "Early Christian prophets and prophecy itself receive minimal treatment by Guy, perhaps suggesting that the book itself is inappropriately titled" (Ib., 4).

8 VI, pp. 781-861. Aune critica la parte de Krämer en Theological Dictionary of the New Testament sobre el paganismo griego, encuentra excelente lo de Rendtorff sobre el A. T., considera un clásico lo de Meyer sobre el judaísmo primitivo (la profecía floreció durante el segundo templo). La parte de Friedrich sobre el N. T., ha llegado a ser lo estandard. Según Friedrich, el profeta cristiano, salvo el Ap, no está por sobre la comunidad. El profeta paulino controla sus sentidos y el uso de su don. Pero este autor, según Aune, no distingue entre lo histórico y la concepción propia de Pablo. "Further, Friedrich's views on the similarities between John the Apocalyptist and OT prophets on the one hand and the contrast between John and early Christian prophets on the other is a view which cannot be substantiated, though it become influential" (Prophecy, 6).

9 Prophétisme dans le Nouveau Testament, DBS VIII, col 1222-1337, en 1972. Bajo la subdirección de este apreciado autor realicé en París, en 1964-1966, una primeriza introducción al tema de la profecía, en el marco de los estudios de doctorado. Ahora retomo, centrándome en las causas de su declinar. Aune expresa respecto a este autor: 'This article, which is 'genre-bound' in the sense that it provides an extensive and generally objective overview of the subject representing the current state of scholarship, is nevertheless a first-rate achievement". "The Roman Catholic theological orientation of the author is evident in the conclusion to this section: Jesus is the prophet par excellence, and Christian prophecy is connected to the promise of Christ to send the Holy Spirit to his disciples. Of these, the Twelve hold the first place" (Prophecy, 6). "In harmony with the leitmotiv throughout the article on the prophetic role in transmitting authentic apostolic tradition, Cothenet proposes that the prophetic gift belonged to the period of foundation, while the construction of the edifice itself belonged to a different type of gifted individual. Yet prophecy has not really ceased, for it is the continuing task of the church to preach in spite of the opposition of the audience" (Ib., 7).

10 Early Christian Prophecy: A Study of Its Origin and Function, Baltimore 1973. Aune califica el libro de Crone como "one of the more significant contributions to our subject 
in recent years" (Prophecy, 7). Es metológicamente superior a las presentaciones anteriores. Dedica la mitad de su libro al marco profético general. Respecto a la religión griega no solo trata de los profetas de oráculos, sino de los predicadores ambulantes. No homogeneíza el judaísmo. En los apocaliptas ve una falta de conciencia profética, pero hay secciones que son proféticas. "Further, the apocalyptists prepared for revelations, which were regularly received in dreams or visions or through past writings, while classical prophets received revelations spontaneously [...] Josephus regards prophecy as a kind of ecstatic possession, as does Philo, though the latter makes greater use of more typical Greek terminology for possession phenomena; for both, prophets are largely figures of the past" (Ib., 8). "Prophecy in Acts was considered a standard manifestation of the reception of the Spirit. Prophets existed in Palestine and Syria; and their functions included the prediction of the future, exhortatory preaching, prayer, and the direction of the community. In Paul prophecy was "a form of preaching whose purpose was exhortation, admonishment, judgement, and instruction, primarily exercised in Christian woship" (Ib., 8). Se juzgan los dichos de los profetas. La falsa profecía de Jezabel tendría influencias helenizantes. Probablemente los profetas eran un grupo distinguible en Ap; en Did son especialistas a tiempo completo, itinerantes, pero algunos instalados. La profecía palestiniana tendría influencias de los movimientos libertarios judíos de la profecía escatológica (advertencias contra falsos mesías y profetas). A los profetas itinerantes los encontramos en Did y en Mt 10, 41 (contrapartida de los predicadores de la religión helenística). "The one comprehensive function of early Christian prophecy was preaching, particularly exhortation or admonition in its enthusiastic or ecstatic form, teaching, foretelling the future, and second sight. The common setting for this activity was the liturgy. Prophecy was a function rather than an office" (Ib., 9). Aune (Ib., 9) termina diciendo: "His study is a model of historical investigation with theological tendencies for the most part remarkably absent". Respecto a profetas itinerantes y residentes, puede verse el mismo Aune, Prophecy, cap. 8, V y la refutación que Boring hace de los itinerantes de Harnack en Continuing Voice, 93-98.

11 New Testament Prophecy, Atlanta 1979. Aune critica como demasiado 'teológica' (crítica que extenderá también a otros aspectos) la definición que da Hill del profeta cristiano: "A Christian prophet is a Christian who functions within the Church, occasionally or regularly, as a divinely called and divinely inspired speaker who receives intelligible and authoritative revelations or messages which he is impelled to deliver publicly, in oral or written form, to Christian individuals and/or the Christian community" (Hill, op cit., 8s; Aune, Prophecy, 10). Solo toca ligeramente las fuentes grecorromanas. Pero su tratamiento de Jesús como profeta está bien hecho, a pesar de su marco inadecuado. 'In discussing the prophetic characteristics of Jesus' ministry (), Hill proposes seven such characteristics: (1) the poetic form of some of his teaching, (2) his visions, auditions, and ecstatic-prophetic experiences, (3) his gift of insight into the thoughts of those about him, (4) his prophetic foresight, (5) his symbolic actions, (6) the phrase 'Amen, I say to you' as an equivalent to the prophetic messenger formula 'Thus says the Lord', and (7) his consciousness of a commission, i. e. of having been sent by God" (Aune, Prophecy, 11). Refiriéndose a Hch, Hill afirma que "the prophetic ministry has the characteristics of pastoral preaching" (Ib., 12). Pablo es un profeta, aunque no se autotitula así. "We may make Old Testament prophets 
completely definitive for our understanding of what is meant by 'prophet' in the New Testament: in which case we may have to say that the apostoles are the real successors of these prophets -as divinely authoritative messengers- and that the New Testament prophets are inferior or secondary bearers of revelation and not genuine "prophets"' (Hill, op cit., 116, Aune, Prophecy, 12). En Corinto, Pablo habría luchado contra influencias del modelo extático griego. Los profetas de Corinto (dos o tres) hablarían más largo, como en una predicación pastoral ( $\pi \alpha \rho \alpha ́ \kappa \lambda \eta \sigma ı \varsigma)$ (cf. Hill, op. cit., 126ss). "A view of the New Testament prophecy that allows it to include a broadly paraenetical function has a significant precedent in the Deuteronomistic conception of prophecy $O$ in which the activity of prophets is largely concerned with (legal) instruction and with warning of people to change their ways (cf. $2 \mathrm{Kgs}$ 17, 13f.; Zech. 1, 4-6, and in later Judaism, Jub. 1, 12; 1 Enoch 89, 53f.; Jos., Antiq, $\mathrm{X}, 60)$ " (Ib., 129). Los profetas son evaluados por otros (no tienen la autoridad de los profetas del A. T.). "In short, Paul is more a prophet of the OT type than are those prophets he attempts to regulate in Corinth" (Aune, Prophecy, 13). Y concluye Aune: "In making Paul's conception of Christian prophecy the norm Hill abandons the perspective of historical criticism and adopts the normative framework of a NT thelogian" (Ib.). "Hill suggests that the Hebrews is an example of written pastoral preaching composed by a Christian prophet" (Ib.). El sufrimiento y muerte de Jesús como profeta en Lucas puede haber sido forjado como ejemplo para los profetas cristianos.

12 "The purpose of the present study is to understand prophets and prophecy as historical phenomena in the history of early Christianity" (Aune, Prophecy, 15). Quiere evitar un acercamiento teológico, normativo. "Not only is it essential then that the Israelite-Jewish prophetic and revelatory traditions be considered in order to understand fully the phenomenon of early Christian prophecy, but the Greco-Roman oracular and prophetic traditions must also be made part of the picture" (Ib.. 17). Salvo Crone, los otros autores presentados han menospreciado lo grecorromano. Pero no hay que comparar aspectos aislados sino la integralidad. Sobre oráculos griegos no hay casi nada. "One major problem of the present study was the almost complete lack of scholarly research on the genre and forms of Greek oracles and oracular speeches" $(I b ., 18)$. Hay pocos estudios sobre la función social de los primitivos profetas cristianos, igualmente sobre los grecorromanos. Tratará de enfatizar esta (cf. Ib., 19).

Salvo en pocas instancias, los autores mencionados ignoran las formas del discurso profético. "In the present study the contributions to the study of the form and genre of Christian prophetic speech have been considered and every utterance which appears to owe its origin to prophetic speech has been analyzed in terms of formal elements, recurring features, and similarities to other forms in Israelite-Jewish and Greco-Roman prophetic tradition" (Ib., 18).

Tratará de distinguir trance de posesión de trance de visión. "H. Bacht has discussed the characteristics of Greco-Roman prophetic inspiration in comparison with early Christian prophecy, with the latter appearing far superior to the former. He proposes five characteristic elements of Greco-Roman prophetic inspiration [...]: (1) a state of divine possession, (2) mantic frenzy (madness), (3) dependence on 
artificial means for inducing the prophetic experience, (4) the initiative for prophetic inspiration is taken by man, frequently through the use of magic, and (5) the content of inspired speech is only occasionally of religious or moral value" (Ib., 21). Pero, según Aune, "Bacht's article, at bottom, is another theologically motivated attempt to make artificial distinctions between the biblical and the nonbiblical world of thought in order to focus on the theologically normative character of the former and the illegitimate nature of the latter" ( $I b$.). También tratará de la relación entre los profetas cristianos y la transmisión de los dichos de Jesús, y de la relación de esos profetas con la interpretación del A. T. Respecto a la comparación de profecía grecorromana y cristiana primitiva, puede verse, Boring, Continuing Voice, 49-51.

13 La influencia helenista ya había llegado al judaísmo.

14 "Most previous reconstructions of the nature and functions of early Christian prophecy have been based on a synthesis of the information available on the subject from the NT and other early Christian literature. No comprehensive attempts have been made to analyze the putative oracles of early Christian prophets and to correlate the results of such an analysis with information about prophet and prophecy. The present study endeavors to accomplish precisely that objective" (Aune, Prophecy, 190).

15 "In our discussions of each of these 107 texts we endeavored to pay close attention to matters of form, structure, style, setting, and function, and to understand these various features in relationship to prophetic traditions of ancient Israel and early Judaism on the one hand, and Greco-Roman paganism on the other [...] One of the more surprising results of our investigation was the relatively large number of texts, or fragments of texts, which appeared to qualify on formal grounds for consideration as possible examples of early Christian prophetic speech" (Prophecy, 317).

16 Cf. Aune, Prophecy, 320-327. Este autor en el apartado 50 del capítulo 12 trata del estilo del habla profética. "The distinctive feature of prophetic speech was not so much its content or form, but its supernatural origin. Christian prophetic speech, then, is Christian discourse presented with divine legitimation, either in the absence of more rational structures of institutional authority, or in conflict with them" (Ib., 338).

17 "The announcement of judgment, the most common form of prophetic speech in the OT, is exceedingly rare in early Christianity. In early Christian prophetic traditions the threat of judgment is usually conditional, and usually occurs in conjunction with conditional promises of salvation" (Ib., 323).

18 Salvación parenética y juicio, parenéticos de confianza, amplificados (p. e. interpretación de oráculos anteriores).

19 Cf. p. e. Prophecy, 192. En general afirma Aune: "Two different kinds of information on this subject are found in this literature: information about prophecy and the activities of Christian prophets, and prophetic sayings and speeches of Christian prophets. These two categories of data must be treated with considerable caution, however. Information about prophecy and the activities of Christian prophets may be idealized (as in Pauline letters?), tedentious (as in Acts?), or idiosyncratic (as in the Apocalypse of John?). Historical criticism is therefore a necessary tool for cor- 
recting and evaluating such evidence. Prophetic sayings and speeches, of course, may be literary creations rather than transcriptions or synopses of the utterances of prophets; or, sayings and speeches of nonprophetic origin may be incorrectly identified as prophetic (e.g. the sayings of Jesus)" (Ib., 190). Y añade en el último capítulo después de un análisis de cada uno de los oráculos: "In the gospels and Acts, therefore, most of the instances of oracular or prophetic speech have a literary origin and were modeled after stereotypical popular conceptions of oracular speech or were based on traditional literary topoi [...] With a few exceptions (e.g. Mark 13, 6.21 and par.; Acts 11, 28; 18, 9; 21, 11; 23, 11; 27, 23-4), the twenty-two 'fragments' of early Christian prophetic speech are not fragments at all, but literary compositions. However, once we shift our attention to the thirty-seven prophetic fragments in the rest of the NT and the forty-eight fragments from early postcanonical literature, the situation changes dramatically. With some exceptions (i.e. Rev. 18, 21-24; 22, 6-7; 22 , 16; 22, 18-20; Hermas Sim. IX, 33, 1) these texts appear to be predominantly genuine, even though they have often been drastically modified to fit their present literary contexts" (Ib., 320).

20 "One guiding principle in the analysis is that spurious oracles and prophetic speeches constitute perhaps better examples of generic and formal expectations than do some legitimate oracles, for they were closely formulated in order to be accepted as genuine" (Aune, Prophecy, 18s).

21 Dentro de su visión más sociológica y un tanto simplista, supone demasiado que los profetas son líderes en las comunidades, que serían desplazado por la creciente organización racional de estas. Concluye la relación de los profetas con los otros líderes de las comunidades, de la siguiente manera: "Prophets were regarded as leaders only insofar as their messages were accepted as divinely inspired and authoritative articulations of the will of God [...] The primary sphere of the prophets' influence was in Chritian congregations assembled for worship. In the absence of the more complex bureaucratic organization which accompanied the institutionalization of early Christianity, prophets appear to have played a more visible and active role in guiding Christian communities in decision making by reiterating the norms and values which were integral part of Christian tradition and by providing the communities with visible evidence of the presence and activity of God and Jesus. The growth of local bureaucracies often in the form of the triad of offices consisting of bishop, presbyters, and deacons, resulted in the increasing exclusion of prophets from active roles in the guidance of the communities. As a visible sign of the unity of the many local scattered congregations, prophets became superfluous when regional organization became a reality" (Aune, Prophecy, 211). Cf. al respecto la síntesis introductoria de Cothenet (Prophétisme, 1264-1267).

22 Respecto a las formas de la profecía grecorromana y del antiguo Israel, se puede consultar los cap. 2-4 de Aune, Prophecy.

23 “Le Maître de Justice est consideré par ses partisans comme celui qui a découvert la véritable interprétation de la Torah (CD III, 13-15) et a saisi le rapport des textes prophétiques avec la vie de la communauté" (Cothenet, Prophétisme, 1226). "Il n'apporte pas de nouvelles révélations, mais prêche le retour à la pratique exacte et 
intégrale de la Torah mosaïque" (Ib., 1227). "The Teacher of Righteousness did not use the word 'prophet' of himself, but functioned as a prophet, speaking from the mouth of God (1QpHab II, 2s), taught by God himself, who has poured out his spirit upon him (7, 4-7)" (Boring, Prophecy. Early Christian, 497). Cf. p. e. 1QpHab II, 2s.7-10; VII, 1-5. Véase 1QH II, 10.13.17s; IV, 27-29; VII, 6s; XII, 11-13. Respecto a recibir en una visión la interpretación de una profecía, véase Dn 9, 2.20-27.

24 “The Qumran sectarians regarded the Teacher of Righteousness as the eschatological Mosaic prophet, just as some early Chritians regarded Jesus as that prophet" (Aune, Prophecy, 126). Su carácter profético es sintetizado así por G. Jeremias respecto al Comentario a Habacuc: "Der Lehrer der Gerechtigkeit ist ein Prophet Gottes. Alle für einen Propheten entscheidenden Merkmale treffen auf ihn zu. Wie die Propheten nimmt er seine Weisungen aus dem Mund Gottes. Er ist von Gott auserwählt, dem letzten Geschlecht das kommende Handeln Gottes kundzutun. Er is von Gott gesandt und beauftragt. Sein Wort stellt die Hörer vor die Entscheidung. Wer den Worten des Lehrers nicht Folge leistet, der is schuldig und geht dem Gericht entgegen. Wer sich an die Worte des Lehrer hält, der wird aus dem Endgericht gerettet [...] Aber eine entscheidender Unterschied besteht zwischen dem Lehrer und den alttestamentlichen Propheten. Die Aufgabe des Lehrers ist es, die Worte der Propheten auszulegen. [...] Alle Worte der Propheten auf die Endzeit beziehen [...] Der Lehrer ist von Gott autorisiert, die Geheimnisse der Prophetenworte su enträtseln" (Der Lehrer der Gerechtigkeit (Studien zur Umwelt des Neuen Testaments, 2), Göttingen 1963, p. 141).

25 "For the Qumran community charismatic exegesis played a functionally equivalent role to prophecy" (Aune, Prophecy, 342).

26 "Selon une constatation qui revient souvent dans les écrits rabbiniques, l'EspritSaint, ou l'Esprit de prophétie, s'est éloigné d'Israël après Aggée, Zacharie et Malachie (Yoma, 9b)" (Cothenet, Prophétisme, 1222). El medio judío del s. I veía a los profetas como anillos de la cadena en la transmisión de la tradición del Sinaí y como anunciadores del futuro; además destaca el aspecto taumatúrgico (Ib., 1224). Según Aune, "In early Judaism prophets of the past, whose words and deeds were recorded in scripture, were primarily regarded as predicters of the (distant) future and as miracle workers" (Prophecy, 153).

"In Pharisaic Judaism Torah -which contains all revealed truth- is the raison d'être of prophets and prohetic activity in that prophets are regarded as the bearers or transmitters of the tradition ultimately derived from that single and supreme revelation" (Hill, op. cit., 31). Para el rabinismo, "the era of prophets had ceased: contemporary 'prophets', in the sense of foretellers of future events, they might accept, but they could not tolerate prophets in the strict sense, prophets who, without reference to Scripture, could proclaim ¡Thus says the Lord! [...] it was an unavoidable consequence of the conviction that the revelation in its totality had been given at Sinai" $(I b ., 37)$. "In keeping with this attestation of charismatic or inspired activity attributed to individual Pharisees is the fact that the Pharisees, as a group, saw themselves as heirs of the great prophetic tradition" (Ib., 35). Según sentencia de Hillel, "s'ils ne sont plus des prophètes, ils en sont les fils" (jSchab 19, 1 (Schwab, IV, 178); bPes., 
6 (Goldschmidt, ed. 1930, II, 509). "The bat qôl (certainly after AD 90) was merely a poor substitute for prophetic revelation, an echo of God's voice, deserving even less attention than the scriptural exegesis of the scribes who, in their own way, laid claim to inspiration" (Hill, op cit., 34).

Aune declara: "Indeed, it has become increasingly recognized that prophecy did not disappear in Judaism during the Hellenistic and Roman periods, but that it was alive and well, though in a form considerably different from that of classical OT prophecy" (Prophecy, 104). Unos de los textos rabínicos más citados respecto a la cesación de la profecía es Tosephta Sotah 13, 2: "When the last of the prophets -i.e. Haggai Zechariah, and Malachi- died, the holy spirit ceased in Israel. Despite this they were informed by means of oracles [bat qol]". Otro pasaje es Seder Olam Rabbah, 30: "Until then, the prophets prophesied by means of the holy spirit. From then on, give ear and listen to the words of the sages" (ambos pasajes tomados de Aune, Prophecy, 103s). Respecto a otros textos, véase Aune, Prophecy, cap. 5 n. 1. Cf. 1 Mac 4, 45s; 9, 27; 14, 41; Sal 74, 9. Véase también s.Bar 85, 3; Flavio Josefo, C Ap, 1, 41 (cf. L. H. Feldman, Prophets and Prophecy in Josephus, JTS 41 (1990) 386-422, p. 400-407). Sobre estos pasajes puede consultarse la interpretación de R. Meyer, Prophetentum und Propheten im Judentum der hellenistisch-römischen Zeit, TWNT, VI, 813-828, p. 814-817, y algunas de las puntualizaciones de J. R. Levison, Did the Spirit Withdraw from Israel? An Evaluation of the Earliest Jewish Data, NTS 43 (1997) 35-57.

27 'Les gens de Qumrân manifestent une grande admiration pour les 'voyants des oracles', consacrés par l'Esprit de sainteté (1QM XI, 7s; CD II, 12; VI, 1, cf. Is 61, 1), comme le marquent en particulier leurs peshârim" (Cothenet, Prophétisme, 1226). "The hermeneutical assumption behind the Qumran pesharim is that all that the prophets wrote was predictive, and those predictions are now being fulfilled" (Aune, Prophecy, p. 124 n.148). Afirma C. Carbullanca N. (Análisis del género pesher en el evangelio de Marcos. Formas y motivos (Anales de la Facultad de Teología, LVIII, 1, Santiago de Chile 2007, p. 416): "Por tanto a partir del estudio realizado en la Parte II, hemos redefinido el género pesher como una forma profética, que parte de la convicción del carácter profético de la Escritura y de otros relatos sagrados. El género está estructurado por una referencia a la Escritura, que conlleva un misterio y que es interpretado escatológicamente. Habitualmente la cita ha sido descontextualizada o modificada para referirla a hechos o personajes que se presentan en los últimos días, los mismos que en ese momento la comunidad de creyentes cree vivir".

28 "The canonization of the Hebrew scriptures, a process largely completed during the first century B.C., had the effect of elevating classical Israelite prophecy to a unique, sacrosanct, and paradigmatic status" (Aune, Prophecy, 81; cf. Ib., 106). Afirma Meyer (op. cit., 828): "Nach dem Untergang der Hierokratie von Jerusalem, der auch eine schwere Nierderlage für alles Charismatikertum bedeutete, konnte der farisäische Rabbinismus an die Schaffung eines palästinischen Patriarchats auf nomistisch-rationaler Grundlage gehen. So kam es zum Abschluss eines festen Kanons und zur Ausscheidung aller Richtungen, die der pharisäisch-rabbinischen Norm nicht entsprachen oder sich in ihr nicht beugten. Gleichzeitig wurde alle Literatur, die den neuen dogmatischen Rahmen sprengte, ausgemerzt und jenem Denkschema zum Siege verholfen, wonach die 'Weisen' die legitimen Fortsetzer der Propheten sind." 
29 'Enfin, ils n'osent pas invoquer directement la parole de Yahvé, à la manière des prophètes (Ainsi parle Yahvé [...]), mais font état de visions, d'extases, de songes qu'ils interprètent ensuite pour leurs lecteurs. Rien n'est plus difficile que de faire la part entre l'expérience vécue par ces auteurs et l'élaboration littéraire" (Cothenet, Prophétisme, 1226).

30 Lc 24, 45.

31 Véase Ef 6, 19s ( $\pi \rho \varepsilon \sigma \beta \varepsilon v ́ \omega)$.

32 "Le charisme de l'interprète est le même que celui de l'auteur inspiré" H. Crouzel, Origène, Paris-Namur 1984, p. 106. Cf. Gregorio el Taumaturgo, Panegírico de Orígenes, $\mathrm{XV}, 179)$.

33 Cf. p. e. Aune, Prophecy, 135ss. Concluye Hill: "To sum up: Josephus knew that the age of immediately inspired and unquestionably authoritative prophecy was past and gone, yet he believed that God still made use of certain individuals for the purpose of revealing the course of future events and guiding the destinies of his people. These could not be called by the honoured title 'prophet', although those who wrongly claimed to be such could be called 'false prophets'. Since Josephus himself believed that he has been entrusted with this kind of task, he was under obligation to provide a context in which the claim could be made credible and intelligible. His political predictions and his activity as an historian provided an available connection with earlier and current understandings of the role of the prophet. A less obvious, but perhaps no less important, aspect of the process of legitimisation arose directly out of his priestly and Hasmonean (therefore high priestly) descent" (op. cit., 31).

Feldman (op. cit., 421s) concluye así: "Josephus'point is that the prophets are the recorders of Jewish history of the biblical period and guarantors of the validity of this account and, indeed, are the predecessors of later historians such as Josephus himself. Inasmuch as prophets play an important role in Greek and Latin literature from the time of Homer himself, he felt that citing the role of prophets, calling them by name as such even in many places where the Bible does not, and Hellenizing their portrait would make them readily intelligible to his pagan readers. Moreoever, the citation of prophecy is, in effect, autobiographical, since Josephus viewed himself, in a certain sense, as being a latter-day Jeremiah, giving advice in the second Temple period similar to that given by his predecessor at the time of the destruction of the first Temple. Though he never refers to himself as a prophet as such, he claimed for himself that aspect of prophecy pertaining to prediction of the future. Finally, his emphasis on the relationship between priest and prophet is largely due to the fact that Josephus is the priest who claimed for himself the gift of prediction".

34 Flavio Josefo, BJ, II, 159. Cf. BJ, I, 78-80; II, 112s; Ant, XIII, 311-313; XV, 372ss; XVII, 346-348 (interpretación de sueño; véase Dn 3, 9 (31)-4, 34).

35 Cf. p. e. Flavio Josefo, Ant, XI, 327. A Juan Hircano atribuye Flavio Josefo el don de profecía (Ant, XIII, 299s (cf. 284); BJ, I, 68s). Puede verse la profecía clerical y la sapiencial, que no eran escatológicas, en Aune, Prophecy, pp. 138ss. El sacerdocio manejó en tiempo antiguos el urim y el tumim. Respecto a Flavio Josefo, véase G. L. Johnson, Josephus: Heir Apparent to the Prophetic Tradition?, en SBL, Seminar Papers, 22, 
Chico, Cal., 1983, 337-346. Respecto a fenómenos proféticos de algunos fariseos y otros, puede verse Meyer, op. cit., 823ss.

"Während nach der Theorie des pharisäischen Rabbinismus sich das Gesetz in den Propheten und deren legitimen Nachfolgern, den Weisen, gleichsam selbst enfaltet, ist es in der alexandrinischen Theologie nach Sap die alles wirkende 'Weisheit', die die Propheten in der Welt kommen lässt" (Meyer, op. cit.., 821; cf. Sab 7, 27). "Somit setzt sich in der Geschichte die Linie der Propheten fort, und im Grunde ist jeder ein Prophet, der die wahre Weisheit als Eingenschaft besitzt" (Ib, 822). Cf. p. e. Filón, Quis rerum, 259. Respecto a Filón, concluye Aune: "Philo was a prophet only in the sense that he consciously regarded the prophetic revelatory experience as the highest source of knowledge, and he himself had experienced the heightened vision into supranormal reality" (Prophecy, 152). Cf. De migr Abr, 35; De cher, 27. Por su parte, concluye Hill (op. cit., 33): "In Philo's writings we find either an acute hellenisation of the Jewish concept of prophecy, or a hellenistic view of prophecy justified on a biblical basis" (la forma más alta del éxtasis; lenguaje griego no bíblico; al alcance de todo hombre digno; eco de la voz del espíritu). Pero Meyer concluía: "Gewiss spricht auch hier Philo in der Sprache des griechischen Weisen; aber in der Sache selbst unterscheidet sich Philo nicht grundsätzlich von ähnlichen Erscheinungen auf dem Boden des palästischen Judentums, mag auch die Begriffswelt zum guten Teile unterschiedenlich sein" (op. cit., 823).

$3611,51$.

37 Afirma Aune (Prophecy, 126): "Eschatological prophets [...] were expected to play a more thoroughly religious role through such activities as the preaching of repentance in preparation for the Day of Yahweh, the definitive interpretation of the Torah, intercession with Yahweh on behalf of Israel, and the performance of miracles as a display of supernatural power and authority".

38 "Most of the schemes of eschatological fantasy current in early Judaism called for the appearance of some kind of messenger of God whose coming could be considered a sign of the end of the age. This messenger was conceptualized primarily in terms of the two categories 'prophet' and 'messiah', which cannot be regarded as completely distinct from each other” (Ib., 153).

39 P. e. Mt 11, 13s; Mc 9, 11-13par. Cf. Mal 3, 23s; Sir 48, 10.

40 Cf. Dt 18, 18ss. Véase p. e. Cothenet, Prophétisme, 1229-1233.

41 Jn 1, 21s.25.

${ }^{42}$ Mc 6, 14spar; Mc 8, 28par; Jn 6, 14; 7, 40; Hch 3, 22s (citando Dt 18, 15.18s; cf. Hch 7, 37), etc. (cf. Friedrich, Pr. im Neuen Testament, V, 5). Juan pregunta a Jesús si es él que que ha de venir (ó ‘́ $\rho$ ó $\mu \varepsilon v o \varsigma$ ) o esperan a otro (Mt 11, 3par). "S’il (Juan) hésite au sujet de Jésus, c'est qu'il ne reconnait pas dans sa manière humble et patiente le programme de purification radicale, prévu par les prophètes. De là la crise douloureuse de Jean en sa geôle. La réponse de Jesús prend toute sa portée si l'on remarque qu'il ne répond pas directement, mais renvoie à l'Écriture et invite de ce fait à lire le plan de Dieu sous un autre éclairage. C'est maintenant l'heure de l'évangélisation des pauvres" (Cothenet, Prophétisme, 1254). Puede verse, por ejemplo, W. 
Kraus, Die Bedeutung von Dtn 18, 15-18 für das Verständnis Jesu als Prophet, ZNTW 90 (1999) 153-176.

43 Las advertencias de Mt 24, 5.11.24 y paralelos contra los falsos mesías de los últimos tiempos, en parte se contextúan en estas experiencias.

44 Cf. Aune, Prophecy, 127-129.

45 Cf. Ant, XX, 97s.167-172.188; XVIII, 85-87; BJ, II, 259-263; VI, 283ss; VII, 437ss. Véase Cothenet, Prophétisme, 1227-1229.

46 "Während der charismatische Priesterfürst das gegenwartige Heil in seiner Person verkörpert, ist der messianische Prophet auf die unmittelbar bevorstehende Zukunft ausgerichtet. Er und seine Anhänger erwarten ein Beglaubigungswunder, wodurch die Legitimität des Propheten erwiesen werden und die Heilszeit ihren Anfang nehmen soll” (Meyer, op. cit., 826). Según Aune, del Mesías davídico, rey, no se esperaban necesariamente milagros. "The Davidic messiah of popular expectation was conceived as a military figure whose primary tasks were the defeat of Israel's enemies, the purification of Jerusalem and the temple, and the ingathering of dispersed Israelites as a prelude for a golden age. This messianic figure did not function as a prophet, a preacher of repentance, or a miracle worker" (Prophecy, 123).

47 Cf. p. e. Lc 7, 16; Jn 6, 14; 9, 17. Véase Lc 24, 19.

48 Mt 12, 38ss; 16, 1-4par; Jn 2, 18-22; 6, 30. Véase Mt 27, 39-43par. C. Grappe compara los signos de Jesús con los de los otros profetas carismáticos de la época ((Jésus parmi d'autres prophètes de son temps, RHPhR 81 (2001) 387-411).

49 Curiosamente la única profecía 'verdadera', de las que trae Josefo a este respecto, fue justamente la de desgracia sobre Jerusalén (BJ VI, 300-309). Coincide con lo que dice Jeremías a Jananías.

50 Concluye Cothenet su presentación de las sobrevivencias del profetismo en el bajo judaísmo: "L'observation intégrale de la Torah, dont on célèbre la pérennité à l'instar de la Sagesse divine (cf. Eccli., 24, 23), polarise les conceptions d'avenir. C'est pourquoi, malgré les survivances du prophétisme que nous avons pu relever, la certitude de l'Église naissante d'avoir reçu l'Esprit et de bénéficier ainsi d'une nouvelle connaissance de Dieu apparaît comme une nouveauté" (Prophétisme, 1233). Antes había expresado, después de constatar la poca resonancia en el judaísmo de la profecía de Joel 3, 1ss: "Nous pouvons conclure avec M.-Al. Chevallier que l'attente d'un nouveau prophétisme constitue pour le judaïsme un élément périphérique dans ses espérances" (Ib., 1229).

51 Puede verse Cothenet, Prophétisme, 1233-1264. "Le Nouveau Testament réserve une place de choix à Jean-Baptiste: nommé 90 fois, il n’est surpassé en fréquence que par Paul et Pierre" (Ib., 1236). Además es atestiguado por Flavio Josefo, por los escritos mandeos. Puede verse también Friedrich, Pr. im Neuen Testment, IV.

52 Mt 11, 9-11par. Cf. Mc 11, 32par; Mt 14, 5.

53 También el Maestro de Justicia pretendía la conversión (cf. Cothenet, Prophétisme, 1240s).

54 Aune (Prophecy, 129) opina: "Yet the baptismal ritual performed by John was much more than a rite symbolizing divine forgiveness. Like the (initial) ritual bath of the 
Qumran community, the baptism of John appears to have functioned as a rite of passage to the eschatological community, the true Israel, who alone would be vindicated by God in the Day of Judgment". "Wer seine Sünden bekannt und die Meidung künftiger Sünden gelobt hat, erhält im Wasserbald des Täufers die Reinheit, die ihn dem bevorstehenden Feuergericht entgehen lässt (Josephus, Ant 18, 117; Mk 1, 14f par.)" (O. Böcher, Johannes der Täufer, TRE XVII, 172-181, p. 176).

55 “C'est lui-même qui baptise en tant qu'envoyé de Dieu et en vue du jugement eschatologique qu'il annonce comme imminent" (Cothenet, Prophétisme, 1246). "Par l'action prophétique du baptême, il suscite le peuple eschatologique des 'pénitents d'Israël', prêts à accueillir le 'plus fort' qui baptisera par l'Esprit et le feu" (Cothenet, Ib., 1261).

56 Cf. Hch 19, 1-7. Puede verse la antigua presentación de Fascher, op. cit., 180-182; U. B. Müller, Johannes der Täufer. Jüdischer Prophet und Wegbereiter Jesu (Biblische Gestalten, 6), Leipzig 2002, pp. 185-197 (Tauferkreise als Zielgruppe des Johannesevangelium).

57 Jn $10,41$.

58 Cf. Jn 8, 26.28.40; 15, 15, etc. Su palabra no es suya sino del Padre (Jn 14, 24). Cf. Jn , 3, 11.32.34; 7, 16; 12, 49; 14, 24. Veinticuatro veces el verbo $\pi \dot{\varepsilon} \mu \pi \omega$ está referido en Jn al envío de Cristo por el Padre. Respeto a Mt 11, 27sspar, afirma Hill (op. cit., 64): "His father has granted him the revelation of himself as completely as only a father can disclose himself to his son: and therefore only Jesus can pass on to others the real knowledge of God. This consciousness of being, in a quite singular way, the recipient and mediator of knowledge of God is implied elsewhere [...]".

59 Jn $1,18$.

${ }^{60}$ Jn 14,9-11, etc.

${ }^{61}$ En Jn 6.

${ }^{62}$ Sobre Él escribió Moisés y los profetas (cf. Lc 24,27.44; Jn 1,45;5,46;12,41; Hch 26, 22s;28,23, etc.). En su día se regocijó Abraham (Jn 8, 56). En él se cumplieron todas las promesas de Dios (cf. 2 Co 1,20). Véase Hch 26,22s; Friedrich, Pr. im Neuen Testament, II,4s. Friedrich exclama: "Jesus ist nicht nur Prophet, er ist Erfüller der Prophezeiungen" (Ib., 845).

${ }^{63}$ Jn 1,17 .

${ }^{64}$ Mc 9,2-7par. "It is probable that we should understand the words 'listen to him' (Mark 9,7 and par.) as intended allusion to the 'him shall you heed' of Deut. 18, 15, and it is in the Transfiguration narrative of Matthew (17, 1-9), together with the Sermon on the Mount (chaps. 5-7) that the Mosaic-prophet theme comes to the fore with clarity" (Hill, op. cit., 54). Aplicado a Jesús en Hch 3, 22s.

65 Según Hill (op. cit., 58), "His claim to possess the Spirit is quite explicit if 'the blasphemy against the Holy Spirit' (Mark 3,29) is rightly interpreted as the denial of the divine source of the spiritual power with which Jesus casts out demons, an activity which indicates that the Kingdom of God, or God's sovereign rule -itself another characteristic theme of Old Testament prophetic proclamation- is breaking through and becoming a present reality in history (Luke 11,20)".

${ }^{66}$ El envío es un tema muy desarrollado por Jn. 
${ }^{67}$ Lc 4, 18s. Cf. Lc 4, 24-29. No anuncia el castigo como el Bautista, sino la misericordia de Dios.

${ }^{68} \mathrm{Jn} 3,34$. Véase Is 11, 2; Mt 12,18.

${ }^{69}$ Cf. Lc 24,48s; Jn 15,26s; Hch 1,8;5,32. Paráclito enviado por él, o como resume Pedro: el Padre le dio el Espíritu y Él lo derramó en Pentecostés (Hch 2, 33; véase Jn 20, 22).

70 Veo que eres profeta, le dice la samaritana (Jn 4, 19; cf. Lc 7, 39).

${ }^{71}$ Cf. Lc 11, 20-22par.

72 Así responde a la pregunta de Juan de si es Él el esperado Lc, 7, 18-22par.

73 "Jésus proclame sa Parole comme ayant autorité par elle-même. Tel est le sens de cet Amen, si souvent répété, dans lequel on a reconnu à bon droit l'un des ipsissima verba Jesu" (Cothenet, Prophétisme, 1268).

${ }^{74}$ Mc 13, 31par.

75 "Jesus ist als Prophet nicht nur Mund Gottes, so dass er seine Verkündigung mit den

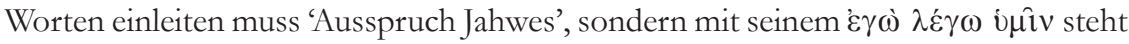
er unmittelbar neben Gott” (Pr. im Neuen Testament, 848).

76 Aune dedica su capítulo 7 a analizarlos: predicciones de la llegada inminente del reino de Dios, de la destrucción de Jerusalén y del templo, de su muerte y resurrección, oráculos de juicio, predicciones de la venida del Hijo del Hombre, discurso escatológico.

77 Lc 13, 33s. Cf. Mt 23, 31par.34par.37par. Véase 1 Ts 2, 15; Hch 7, 52; Rm 11, 3; Asc Is, 5 (cf. Hb 11, 37); 5 Esdras 1, 32. Véase Friedrich, Pr. im Neuen Testament, II, 6.

78 Jn 16, 13.

79 Por eso no entro en la exacta reconstrucción del Jesús histórico en el aspecto profético, que está en la base de varias de las explicitaciones de la fe recién reseñadas.

${ }^{80}$ Mc 6, 15par; 8, 28par; 14, 65par; Lc 7, 16; Mt 21, 11.46; Lc 24, 19; Jn 6, 14; 7, 40. Véase Lc 7, 39; Jn 4, 19; 8, 7-9; 9, 17; Hch 3, 22s (7, 37). Cf. Hill, op. cit., cap. 2, 1. Y según Aune, "The four gospels contain a number of reflections of the popular view of the identity and significance of Jesus in which the title 'prophet' ist prominent" (Prophecy, 153). "In sum, only in Acts and John is Jesus identified with the prophet like Moses [...] Luke shows a greater interest in the status of Jesus as a prophet, yet for him that title is primarily a vehicle for understanding Jesus as one who shared the typically violent fate of the prophets" (Ib., 156). Cf. Mc 6, 4par y Lc 13, 31-33. De ahí concluye Aune que es muy probable que Jesús haya identificado su propia misión con la de los profetas del antiguo Israel (Ib., 156s). "Without using 'prophet' as a direct self-designation, Jesus clearly indicates that he understands his role in prophetic terms in so far as it involved rejection, persecution and matyrdom" (Mc 6, 4par; Lc 13, 33) (Hill. op. cit., 57).

"Dodd suggests five reasons why Jesus was popularly regarded as a prophet by his contemporaries: (1) the sovereign authority of his teaching (Mark. 1, 27), implied by the characteristic introductory phrase '(Amen) I say unto you', (2) the poetic 
character of his sayings, in contrast to rabbinic teaching, and reminiscent of the style of the OT prophets, (3) his experience of visions and auditions (Luke 10, 18), (4) he, like the prophets of old, was thought to have made many predictions (Matt. 23, 38par. Luke 13, 35; Mark 13, 2; 14, 58) and (5) Jesus, like the OT prophets, performed symbolic actions. Turning to Jesus' teaching, Dodd finds four more reasons in features which are reminiscent of the OT prophets: (6) Jesus rejected the formalism of contemporary Judaism for a more vital form of religion, (7) Jesus rationalized the popular apocalyptic fantasies in terms of historical possibilities of the Roman menace, (8) Jesus announced the reign of God in opposition to the power of evil, and (9) as a preacher of repentance, more than a teacher, Jesus exercised a distinctive prophetic function. Finally, Dodd enumerated six additional personal traits of Jesus that he regarded as having an affinity with the OT prophets: (10) Jesus was conscious of special calling which he expressed in a variety of ways $[\ldots]$; (11) Jesus received divine revelation through intimate communion with God (Matt. 11, 27par. Luke 10, 22); (12) Jesus represented God; to follow him is to obey God, to reject him is to reject God (Mark. 9, 37; cf. 1Sam. 7, 7; Ezek. 33, 30-33); (13) Jesus was conscious of a mission to all Israel (Matt. 15, 24; 19, 28par. Luke 22, 30); (14) like the prophets, who no only proclaimed the word of God but also consciously participated in its fulfilment, Jesus expected some momentous consequence from his death; and (15) Jesus exhibited what could be called 'prophetic piety"' (Aune, Prophecy, 160).

81 "The prophetic status of Jesus, from his own perspective as well as from that of many of his contemporaries, was based upon his proclamation of the imminent arrival of the kingdom of God and the wonders which he performed as a way of legitimating that proclamation. The various sayings of Jesus which have the form of predictions of the future, wether they concern the destruction of the temple, announcements of coming judgment, the coming of the Son of man, or his own death and ultimate victory, all relate in a fundamental way to his proclamation of the imminent arrival of the kingdom of God" (Aune, Prophecy, 171). Y añade: "While Jesus apparently regarded himself as a prophet, and some of his contemporaries regarded him as a prophet, he made no attempt to legitimate his message through the use of traditional introductory prophetic formulas" (Ib.). Boring (Continuing Voice, 57) concluye así su resumen: "Here I can only state that Christian scholars of the most varied theological positions have generally agreed that the New Testament's picture of Jesus as prophet is historical bedrock".

82 'The early church, though it preserved traditions of Jesus' prophetic status both in the popular view and in terms of his own consciousness, did not regard the title 'prophet' as adequate to express the developing conceptions of the significance of Jesus" (Ib., 188). Respecto a la tendencia que tuvieron los judeocristianos de solo ver en Jesús un segundo Moisés, afirma Cothenet: "On comprend aisément que S. Paul ait combattu cette typologie (2 Cor., 3, 4-18), qui risquait de faire perdre de vue la trascendance du Christ, et ait développé par contre la typologie Adam-le Christ” (Prophétisme, 1269). Tampoco prosperó 'siervo de Dios', categoría profética del segundo Isaías, que fue clave para la comprensión de la muerte de Jesús. Cf., p. e., la catequesis de Felipe al eunuco en Hch. En general, lo que los oídos griegos no entendían, como 'Hijo del hombre', tiende a desaparecer. En este sentido 'Cristo' se salvaría porque fue asociado con 'Jesús', etc. y evolucionó hacia el nombre propio. 
83 No es el simple hijo de Dios, como podía ser el Mesías o el justo. Ya destacamos el título 'Señor'. Así lo llama Pablo, pero para explicarlo un poco más, habla del 'Hijo'. Respecto a la posterior presentación de Jesús como el profeta verdadero, como el profeta del Deuteronomio, en las pseudoclementinas, puede verse p. e. H. J. Schoeps. Theologie und Geschichte des Judenchristentums, Tübingen 1949, pp. 98-116; Friedrich, Pr. in der alten Kirche, II.

${ }^{84}$ El mismo envío de los apóstoles tiene una similitud con la misión profética. "Rien de semblable n'est relaté dans la vie des prophètes" (Cothenet, Prophétisme, 1270). "L'autorité souveraine avec laquelle Jésus envoie se marque par la formu-

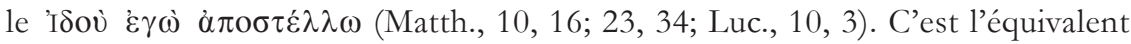
d'une tournure oraculaire de l'Ancien Testament [...] Ici ce n'est plus son Dieu qui envoie, mais Jésus avec toute l'autorité de son ' $₹ \gamma \omega \omega^{\prime \prime}(I b$.). Y en Mt 13, 11par y 16spar son declarados superiores a los profetas y justos del A. T., porque están en los tiempos del cumplimiento, porque se les ha dado a conocer los misterios del reino. Y serán perseguidos (Mt 23, 34par).

85 Cothenet, Prophétisme, 1277. Cf. Lc 24, 49; Jn 15, 26s; 16, 7.13-15, etc.

86 Gloriosa alianza, no de la letra sino del Espíritu (2 Co 3, 6).

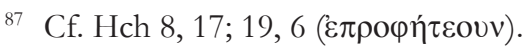

88 Hch $2,17 \mathrm{~s}$.

891 Co 12, 7ss. Los hijos de Dios son conducidos por el Espíritu (Rm 8, 14).

90 "But there is ample evidence that even those eartly Christians, such as Paul and Luke, who affirmed that every member of the community was empowered by the Spirit (Acts 2, 38; 19, 1-7; 1 Cor. 12, 3.13) still did not regard every Christian as a prophet, even though both associate the Spirit with prophecy (Acts 2, 17-18; 13, 1-2; 19, 6; 21, 10-11; 1 Thess. 5, 19-20; Rom. 12, 6; 1 Chorinthians 14 throughout, especially v. 37). On the contrary, both Paul and Luke distinguished the general gift of the Spirit from the specific manifestation of prophecy (Acts 13, 1; 11, 27-28; 15, 32; 21, 9-11; 1Co 12, 29; 14, 29)" (Boring, Continuing Voice, 42).

91 Cf. 1Co 12, 10.29; 14, 1.5.39 (véase 14, 24). Véase Num 11, 29. Justamente antes de declinar el oficio de profeta, surge este deseo. "The prophet in the strict sense is not a sharply marked off from the rest of the community as in the Old Testament and Judaism” (Boring, Continuing Voice, 42; cf. Ib., 99s). Respecto a cierta universalización de la profecía, puede verse Sb 7, 27; Filón, Quis rerum, 259.

92 Prophétisme, 1289s. Cf. 2 Ts 2, 2.

93 1Co 12, 3. A propósito de Lc 1,43, escribe Cothenet: "Déjà il apparaît que le role fondamental de l'Esprit est de faire reconnaître en Jésus le Kyrios" (Prophétisme, 1276).

94 "In der Apg dient die Prophetie dazu, besonders Individuen für spezielle Aufgaben zu erwählen (Apg 13, 1-3), Hilfe in Entscheidungssituationen zu bieten (16, 6-10), die Zukunft vorherzusagen (11, 27f); 20, 23; 21, 20f) und Streitigkeiten zu schlichten (15, 28.32)" (Aune, Prophet/Prophetin/Prophetie. Neues Testament, RGG ${ }^{4}, \mathrm{VI}$, 1702-1704, col. 1704). Según Boring (Continuing Voice, 73-75), las cuatro tendencias interpretativas de Lucas en Hch serían: 1) Los profetas cristianos (y Jesús) son puestos en la sucesión de los del A. T. y se les parecen; 2) El retrato de los profetas 
en Hch, incluyendo a Pablo, es uniformemente no escatológico; 3) valorización del testimonio del fenómeno (manifestación del don escatológico del Espíritu y de ser continuación del pueblo de Dios del A. T.) y no tanto el contenido de los oráculos; 4) el rol de los profetas en la conducción de la Iglesia es más bien decorativo frente a Apóstoles y presbíteros. No quiere presentar a la Iglesia como parecida a una asamblea de profetas paganos.

Respecto al evangelio de Lucas, afirma Hill (op. cit., 94): “The Spirit, as the presence and power of God, is the life-giving agent in the birth of the one who inaugurates the New Age (Luke 1, 35): the conviction that the New Age has indeed come is strongly demonstrated by Luke's emphasis on the presence of the Spirit of prophecy throughout his birth narratives concerning John the Baptist and Jesus [...]. The third evangelist, more than the other Synoptists, lays emphasis on the role of the Spirit in the Christian life". Respecto a Hch 4, 31, expresa este autor: "Being filled with the Spirit' would, in Jewish usage, be tantamount to saying 'becoming prophets' (cf. 2, 38c), and, in that capacity, with the inspiration of the Spirit, the disciples testify to their faith in the face of hostile opposition" (Ib., 96).

95 Por ejemplo a Pedro en lo de Cornelio, a Felipe en lo del eunuco. Da la $\pi \alpha \rho \rho \eta \sigma i ́ \alpha$ para el testimonio. Véase Hch 5, 32. La predicación de la Palabra va acompañada de signos.

96 Hch 13, 1s. 'L'union étroite entre 'prophètes et didascales' à Antioche (Act 13, 1) montre que la prophétie ne se déployait pas à l'aventure, mais à l'intérieur d'un espace doctrinal dont les apôtres et les docteurs avaient spécialement la garde" (E. Cothenet, Prophétisme et ministère d'après le Nouveu Testament, Maison-Dieu 107 (1971) 29-50, p. 34s).

${ }^{97}$ Hch 20, 22s; 21, 4.10s. El Espíritu les impidió entrar en Asia y Bitinia (Hch 16, 6-10).

98 "Ainsi donc les Apôtres, entourés du collège des presbytres, apparaissent comme les organes de l'Esprit dans la conduite de l'Église. De ce point de vue, ils font l'office de prophètes, car ils parlent au nom de Dieu et manifestent le vouloir actuel de Dieu sur les destinées de son peuple" (Cothenet, Prophétisme, 1279).

99 Cothenet agrega a los llamados profetas en Hch, a Bernabé, Esteban y Felipe (cf. Prophétisme, 1280-1285). Véase Hch 6, 10; 7, 55ss; 8, 6s.13.26.29.39s, etc. "In all, Acts refers to twelve specific individuals who prophesy, more than all the rest of Christian literature combined" (Boring, Continuing Voice, 73). Los profetas Judas y Silas que

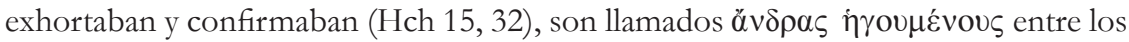
hermanos (Hch 15, 22). De las cuatro vírgenes, hijas de Felipe, se afirma $\pi \rho \circ \varphi \eta \tau \varepsilon v ́$ ovoar (Hch 21, 9). Puede verse E. E. Ellis, Prophecy and Hermeneutic in Early Christianity (WUNT, 18), Tübingen 1978, cap 8: The Role of the Christian Prophet in Acts.

${ }^{100}$ Fórmula propia de la profecía cristiana.

101 ¿Propia de los tiempos escatológicos? En general, respecto a Hch, afirma Hill (op. cit., 108): "it is clear that for the author of Acts prediction is not the main function

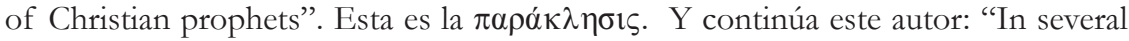
important passages Christian prophecy, as an eschatological gift or power of the Holy Spirit, is a possibility for any believer, but it is primarily identified with certain leaders (Acts 15, 22) who exercise it as a continuing ministry" (Ib.). 
$1021 \mathrm{Tm} 4,14$. Cf. 1, 18. "The notion of divine commission mediated through prophetic spokemen may also be reflected in Paul's speech to the Ephesian elders in Acts 20, 27ff" (Aune, Prophecy, 266). En Hch 1, 23-26 se pide a Dios que indique el reemplazante de Judas Iscariote en el grupo de los doce apóstoles y se tira a la suerte entre Matías y José Barsabás. Véase $1 \mathrm{Cl}$ 42, 4; Clemente Al., Quis dives, 42, 2 (Eusebio, HE, III, 23, 6).

${ }^{103}$ Eusebio, HE, III, 5, 3; Epifanio, De mens et pond, 15 (PG 43, 261B).

104 "There is every probability that a prophetic summons to flight was mediated to the Christian community in Jerusalem by a prophetic or angelic messenger just before or during the first Jewish revolt" (Aune, Prophecy, 312). "And it would certainly have implied if not badly stated the imminent destruction of Jerusalem" (Ib.).

105 "Die Korinther haben die glossolalie als die eschatologische Manifestation des Geistes geschätzt $(14,1.12)$, als $\sigma \eta \mu \varepsilon i o v ~(14,22)$ und zwar wegen ihrer Eigenschaft als eines Sprechens in Engelsprachen (vgl. 1 Kor. 13, 1)" (G. Dautzenberg, Botschaft und Bedeutung der urchristlichen Prophetie nach dem ersten Korintherbrief (2, 6-16: 12-14), en J. Panagopoulos, Prophetic Vocation in the New Testament and Today (Suppl. N. T., 45), Leiden 1977, 131-161, p. 134; cf. Idem, Glossolalie, RAC XI, col. 225-246.). La glosolalia participaba en la alabanza celestial y se sumergía en los misterios (cf. 1 Co, 14, 2.14-17). Respecto a Hch 10, 46 y 19, 6, expresa Cothenet: "Dans ces deux cas, la glossolalie ne se caractérise pas par une 'communication' aux hommes, mais par une forme extatique de louange de Dieu, et l'on songe à la glossolalie de Corinthe (1 Cor., 14), interprétée comme prière dans la langue des anges (1 Cor., 13, 1)" (Prophétisme, 1278). Glosolalia y profecían van juntos en Hch 2, 4 (llenos del Espíritu Santo) y 17; $19,6$.

106 "Aus 1 Thess. 5, 19-21 und 1 Kor. 14, 26-32 ist zu entnehmen, dass diejenigen, die Prophetie betrieben, nicht etwa ein Amt innehatten, sondern regelmässig prophetische Funktionen wahrnahmen und aus diesem Grund Propheten gennant werden konnten" (Aune, Prophet, col. 1703).

1071 Co 14, 2-25. "In short, he removed these manifestations of the spirit, including prophecy, from a context of selfish and prideful individualism and set them in a context of community, accountability, mutual development, good order, intelligible worship and ministry on behalf of others" (C. M. Robeck, Prophecy, Prophesying, Dict of Paul and His Letters, 755-762, p. 758). La profecía es parcial y temporal (1 Co 13, 8s).

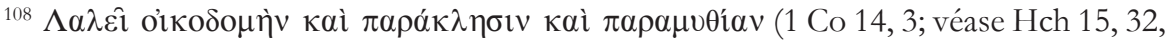

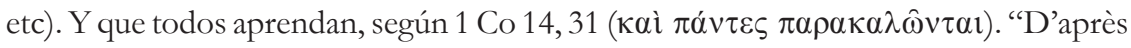
les indications de 1 Co., 14, 3, on assignera aux prophètes un rôle d'explication des desseins de Dieu à partir de l'Écriture et de soutien des communautés dans l'épreuve. Leur rôle dans la liturgie est probable, vu l'importances que nos épîtres (de la cautividad) donnent aux cantiques inspirés par l'Esprit-Saint" (Cothenet, Prophétisme, 1310; véase Did 10, 7). Respecto a la edificación, puede verse J. D. G. Dunn, Jesús y el Espíritu. Un estudio de la experiencia religiosa y carismática de Jesús y los primeros cristianos tal como aparece en el Nuevo Testamento (Koinonia, 9), Salamanca 1981, pp. 368-374. 
1091 Co $14,24 \mathrm{~s}$.

1101 Co $14,30$.

1111 Co 14, 26-34.40. Que hablen dos o tres profetas, etc. Probablemente hablaban largo. ¿Hay desviaciones debidas a la influencia grecorromana (cf. 1 Co 12, 2)? Cf. Hill, op. cit., 121s. Según C. Forbes (Prophecy and Inspired Speech. In Early Christianity and its Hellenistic Environment, Peabody, Mass. 1997, pp. 260ss y 320s), lo que Pablo combate es el elitismo de los espirituales. ¿Ha llegado alguno a maldecir a Jesús (1 Co 12, 3) o, como sostiene Aune (Prophecy, 256s), esto solo constituye un contraste literario a que solo en el Espíritu se proclama a Jesús como Señor? La confrontación con el paganismo (adivino consultado) será clara en el Mandamiento XI de Hermas.

1121 Co 14, 32. "Or those intending to speak might exercise self-control (1 Cor 14, 32), even to the point of deferring to another individual who, while sitting in their presence, receives what appears to be a pontaneous revelation (1 Cor 14, 30" (Robeck, op. cit., 758).

1131 Co 14, 34-36 (véase 1 Co 11, 4ss). Véase, por ejemplo, G. Dautzenberg, Prophetie bei Paulus, JBTh 14(1999)55-70, p. 55-57; A. Lindemann, Der erste Korintherbrief (HNT, 9, 1), Tübingen 2000, 316-321 (sobre la posible interpolación).

${ }^{114}$ P. e., 1Co, 14, 29. Véase 1 Co 12, 10; 1 Ts 5, 19-21. "But who are the 'others' to whom Paul made reference here? Many have suggested that Paul envisioned a group of 'prophets' who might weigh or test the oracle, but it is more likely that Paul saw a role for the entire congregation in this regard. Paul's injunction in 1 Thessalonians 5, 20-21 that prophecy should not be despised but tested is not limited to a group of testing 'prophets'. It appears to be a congregational mandate" (Robeck, op. cit., 760).

115 Sobre el uso de los términos, puede verse Ellis, op. cit., cap. 2.

116 1Co 14, 37.

117 1Co $14,1$.

${ }_{118}$ 1Co 12, 28s; Ef 4, 11. Cf. Rm 12, 6. "The listing 'first apostles, second prophets, third teachers' in 1 Corinthians 12,28 , for instance, seems not to be formulated ad hoc, but to represent a fragment of an earlier church order with Palestinian-Syrian connections" (Boring, Continuing Voice, 65).

119 Respecto a Ef, opina Boring: "The earlier charismatic ministry is remembered with gratitude, but it is only a memory and has given way to a more structured, ordered ministry in the later Pauline churches... The memory persists even in the author's time that a theological decision of momentous import, the decision to include the Gentiles within the church, was not based on the teaching of the historical Jesus but was a matter of postresurrection revelation 'in the spirit' to apostles and prophets $(3,5)$. This fading away of the prophetic gift, strictly defined, seems to have happened without a crisis, without any suspicion or denigration of the prophetic phenomena" (Continuing Voice, 67).

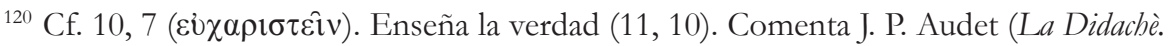
Instructions des Apôtres (Études Bibliques), Paris 1958, p. 432): "Une telle liberté revenait, en effet, comme naturallement aux 'prophètes', dans les conceptions du judaïsme de l'époque, très influencé là-dessus par l'exemple de David et le recueil des Psaumes. La ‘bénédiction' y était devenue, par excellence, expression 'prophétique"'. "Die 
Gottesdienst- und Abgabenordnung $(10,7 ; 13,3)$ scheint niedergelassene Propheten vorauszusetzen, die Didache rechnet aber ebenso mit wanderden Propheten (11, 1-3.7; 13, 1)" (G. Dautzenberg, Propheten/Prophetie. Neues Testament und Alte Kirche, TRE XXVII, 503-511, p. 508). Habría que discernir los itinerantes.

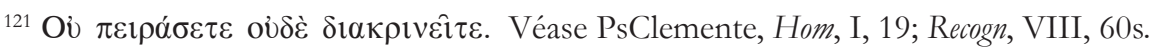

${ }^{122}$ Cf. 11, 7. Véase Mc 3, 29par.

${ }^{123}$ Cf. 11, 11. Así lo hacían los profetas antiguos. ¿Serían acciones simbólicas respecto al matrimonio, que podrían escandalizar en una comunidad de ideal más ascético, y que no eran las maneras de Jesús? Varios lo han interpretado como matrimonio espiritual, que simbolizaba la unión entre Cristo y la Iglesia (cf. K. Niederwimmer, Die Didache (Kommentar zu den Apostolischen Vätern, 1), Göttingen 1989, ad l. c.).

${ }^{124}$ Cf. 13, 3-7. Interpolación, según Audet, ad l. c.

${ }^{125}$ Cf. 15, 1s. También ellos desempeñan el oficio de profetas y doctores, por tanto son

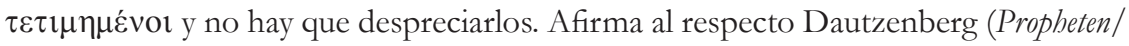
Prophetie, 509) "Das bedeutet dass die ortansässigen Propheten als charismatische Gemeindeleiter fungiert haben. Der Übergang zu einer episkopalen Gemeindeordnung ist zumindest im Traditionsbereich der Didache weniger auf die Eigendynamik einer Entwicklung zu kirchlichen Ämtern als auf den Rückgang der Prophetie zurückzuführen”. Está en correlación con el cambio de la perspectiva escatológica de una espera próxima a una lejana ("damit verliert die Prophetie ihren eigentlichen Ansatzpunkt” (Ib.). Según R. A. Kraft (The Apostolic Fathers. A New Translation and Commentary. III: Barnabas and the Didache, New York 1965, p. 174), "This is one of the most recently composed sections of the Didache 0, reflecting the transition from dependence on itinerant ministers, some of whom have settled $(13,1 \mathrm{f})$, to indigenous leaders". Antes había dicho $(I b, 67 \mathrm{~s})$ respecto a la comunidad en relación a los profetas: "it must be warned not to exercise too much control over prophets $(10,7$; $11,7 ; 11,11 \mathrm{f})$ and not to despise native leaders $(15,2)$ !".

${ }^{126}$ Según el texto de Did 13, 4. Interpolación, según Audet, ad l. c.

${ }^{127}$ Mt 10, 41. Según Did 13, 1, un profeta se puede establecer en la comunidad. "Le juste est celui qui enseigne la justice (cf. Dan. 12, 3) et son rôle correspond à celui du didascale" (E. Cothenet, Les Prophètes chrétiens dans l'Évangile selon saint Matthieu, en M. Didier, L'Évangile selon Matthieu. Rédaction et théologie (BETL, 29), Gembloux 1972, 281-308, p. 298). Según Boring (Continuing Voice, 70), "Matthew was apparently able to embrace his whole community in the thrice-repeated 'prophets' and 'righteous' $(10,41 ; 13,17 ; 23,29)[\ldots]$ As the Old Testament congregation was composed of prophets (leaders) and righteous (pious people, lay preople), so Matthew sees his own church [...] Like Schweitzer, Sand sees prophecy as the category in which Matthew interpreted discipleship to Jesus as such". "Our earliest source for Palestinian Christianity is the hypothetical document Q, which is often considered a witness to the prophetic nature of earliest Christianity" (Boring, Prophecy. Early Christian, 499). Respecto a Q, puede verse Hill, op. cit. 152-154.

${ }^{128}$ Mt 7, 22 (o expulsaron demonios e hicieron milagros en el nombre de Jesús). Cf. Justino, Dial, 76, 5. Véase Mc 13,11par (cuando sean entregados, el Espíritu hablará en ellos); 16, 17 (hablarán en nuevas lenguas); Lc 12, 10par (el que blasfeme contra el 
Espíritu Santo, no será perdonado). Según Mt 23, 34, Jesús promete enviar profetas, sabios y escribas, los que serán perseguidos (cf. Cothenet, Prophétisme, 1271s).

${ }^{129}$ Respecto a la autocomprensión de Pablo como profeta, cf. Boring, Continuing Voice, 61-65. "The figure of the apostle in the early church, and especially in Paul, is modeled largely on the role of the prophet in Israel as God's representative, who has been called and commissioned by God himself $[\ldots]$ As an apostle he speaks in tongues (1 Cor. 14, 6.18) and works miracles (2 Cor. 12, 12; Gal. 3, 5); as an apostle he can and does prophesy (1 Cor. 14, 6; 1 Thess. 4, 15-17)" (Ib., 61s).

${ }^{130}$ Cf. p. e. C. A. Evans, Paul as Prophet, Dictionary of Paul and His Letters, 762-765, p. 763s. "Modern scholars, however, are quite willing to caregorize him as a prophet. From the standpoint of early Christianity the role of apostle appears to have been a functional equivalent of the OT prophet" (Aune, Prophecy, 248). Cf. p. e. 1 Co 14, 6; 1 Co 7, 40; 2 Co 13, 3. Según Hill (op. cit. 116-118), si aplicamos el concepto de profeta del A. T., los apóstoles serían sus verdaderos sucesores, como mensajeros divinamente autoritativos, pero el concepto había llegado a ser menos estricto y más general por la donación del Espíritu a toda carne (Joel 2,17s) y por el uso común y literario. Así se pudo aplicar a los llamados 'profetas'.

Entre otras cosas, concluye K. O. Sandnes (Paul-One of the Prophets? (WUNT, II, 43), Tübingen 1991, p. 240): "Paul really did conceive of his apostolate and his commission to preach the gospel to the Gentiles in prophetic terms". "Prophetic features appeared in prescriptiones (e.g. Rom 1, 1-5), in apologetic texts (e.g. Gal 1, 15-16; 2 Cor 2, 16; 3, 5-6), in argumentative texts (1 Cor 9, 15-18; Rom 10, 14-18), and in a thesis-text like 1 Cor 2, 6-16, and accordingly Paul used this propheticapostolic self-understanding for different purposes" (Ib., 241). "In order to be recognised as an apostle Paul invokes a revelation of Christ. The challenge he was faced with was to argue that this was no private revelation (cf. 2 Cor 12, 1-5 [...]) but had to be considered as an act of inauguration. In this situation Paul legitimises his call and apostolic task by referring to the biblical prophets as models. For the biblical tradition on the prophets witnesses to revelation and visions as God's way of assigning a prophet in his task" (Ib., 242). Y en referencia a Ef 2, 19-3, 7, añade este autor: "There are two, relatively different, kinds of prophets in the NT: The apostleprophet, and the early Christian prophets. The apostle-prophet we consider in many ways a successor to the OT canonical prophets, while the early Christian prophets stand within the wider stream of prophecy in OT, Judaism and the Greco-Roman world" (Ib., 245s). La vocación de Pablo es de una vez para siempre, y respecto a un evangelio que no podía ser cuestionado. Su predicación del misterio era fundacional.

131 P. e. Ga 1, 11-17, etc.. Será testigo (Hch 22, 15.18; 23, 11; 26, 16.22, etc.).

${ }^{132}$ Cf. Ga 1, 16; Hch 9, 15; 22, 21; 26, 17s. Véase Rm 1, 5; Ga 2, 7.

${ }^{133}$ Hch 13, 9-11. En Hch 16, 16-18 aparece una pitonisa, cuyo espíritu expulsa Pablo (véase Hch 19, 13-17). Cf. Herm, Mand XI, 43, 3. Recordemos que los falsos Cristos y profetas, también harán milagros (Mc 13, 22par; véase 2 Ts 2, 9; Ap 13, 13-15; 16, 13s; 19, 20; Did 16, 4; Ap Petr, 2; Justino, Dial, 7, 2; Syb, II, 165-168; Tertuliano, Praesc, 44, 5s). Véase Dt 13, 2-6. Es clásica en los tiempos apostólicos la figura de Simón el Mago (cf. p. e. Ireneo, Adv Haer II, 31, 2s; Act Petr, 23ss;32; PsClemente, 
Hom, II, 33). Esto destaca más el problema del discernimiento. Con todo, los signos de Moisés en Egipto fueron más potentes que los de los magos.

${ }^{134}$ P. e. Rm 15, 19; 2 Co 12, 12.

${ }^{135}$ Véase Hch 19, 11s, etc.

${ }^{136}$ Cf. 1 Co 2, 12-16 (cf. 2, 6ss). G. Dautzenberg (Botschaft, p. 139ss; cf. Idem, Prophetie bei Paulus, 68-70) destaca los elementos proféticos en 1 Co 2, 6-16. Véase 1 Co 7, 40. Según Cothenet, "Alors que S. Luc, par exemple, met surtout en valeur l'influence extérieure de l'Esprit dans la croissance de l'Église, S. Paul développe un enseignement très profond sur l'action de l'Esprit dans l'âme de tout baptisé" (Prophétisme, 1288s).

${ }^{137}$ Cf. 2 Co 12,1 ss.

${ }^{138}$ Cf. Hch 18, 9s; 22, 17-21 (cae en éxtasis); 23, 11. Véase Hch 9, 12; 16, 9; 26, 16; 2 Co 12, 7; Ga 2, 1 s.

${ }^{139}$ Hch 27, 22-25.

${ }^{140}$ Cf. Rm 16, 25s. Véase Col 1,25-27; Ef 3, 2-9 (los gentiles son coherederos, concoporales, coparticipantes de la promesa en Cristo Jesús mediante el evangelio; el misterio ahora ha sido revelado a sus santos apóstoles y profetas por el Espíritu), etc. Véase Ap 10, 7. Según 1 Co 2, 7ss, el misterio les fue revelado por el Espíritu. Véase 1 Co 13, 2. Varios autores creen que Pablo cumple una función profética en los misterios que comunica en Rm 11, 25s y 1 Co 15, 51. Puede verse también H. Merklein, Der Theologe als Prophet. Zur Funktion prophetischen Redens im theologischen Diskurs des Paulus, NTS 38 (1992) 402-429. Respecto a 1 Co 13, 2 en el caso que $\varepsilon 1 \delta \hat{\omega}$, etc, sea explicativo y no aditivo, afirma Lindemann (op. cit., 284): "Gegenstand der

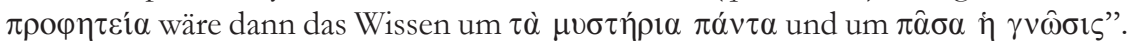

${ }^{141}$ Quien mintió al Espíritu (Hch 5, 3s).

142 Tiene visiones, es liberado por un ángel, hace milagros y termina muriendo mártir (cf. Jn 21, 18s), entre otras cosas. Lucas establece un paralelismo entre los hechos de Pedro y de Pablo.

143 “Le prophétisme chrétien se rattache à la promesse du Christ d'envoyer l'Esprit divin à ses disciples; parmi ceux-ci, il faut compter au premier rang les Douze, qu'il a choisis de sa propre autorité et auquels Il a communiqué une révélation supérieure à celle des prophètes et des justes de l'Ancienne Alliance. On ne saurait donc traiter du prophétisme sans tenir compte et de l'apostolat et de la 'tradition'. La plus grave critique qu'il faut adresser à Bultmann et à son école, c'est d'avoir fait abstraction du rôle des Douze comme témoins privilégiés de la 'sainte tradition de Jésus"' (Cothenet, Prophétisme, 1285).

144 Prophétisme, 1304-1309. “En tant qu'apôtres ils sont les témoins tout puissants et par là les représentants de Jésus, pasteur et prêtre; en tant que prophètes, par contre, les authentiques maîtres et messagers de la révélation reçue par eux" (Ib., 1308, en cita de Pfammatter). "In other words, what we have in Ephesians 2, 20 and 3, 5 is a twofold designation of the founders of the church and of those to whom there was revealed the 'mystery' of the Gentiles' inclusion therein: they are 'apostles' in that they are the authoritative witnesses to, indeed the representatives of, Jesus; and they are 'prophets' by virtue of the fact that they are authentic messengers and agents of the revelation they received" (Hill, op. cit., 139). 
145 “Le prophétisme déborde le cercle de l'apostolat, mais c'est dans ce dernier que se vérifie dans toute sa force la nature du prophète comme messager de Dieu, établi comme autorité pour fonder l'Église" (Cothenet, Prophétisme et ministère, 39).

146 Aune (Prophecy, 202) dirá de paso: "In many respects the NT apostle was the functional equivalent of the OT prophet". Recordemos que comunican el Espíritu por la imposición de manos. A este respecto, L. Cerfaux se había expresado así: "Puisque la prophétie chrétienne continue celle de l'Ancien Testament, elle doit garder son double profil. Les 'nabis', fils de prophètes, cultivent l'extase et prophétisent d'une manière très libre et relativement désordonnée, tandis que les prophètes de vocation se mettent au service de Dieu pour accomplir une mission déterminée. Les apôtres, à côté des prophètes proprement dits, joueront le rôle des grands prophètes de l'Ancien Testament. Les prophètes charismatiques rejoignent les fils de prophètes, bien qu'il faille les soumettre davantage, dans l'organisation que saint Paul leur impose, au contrôle de l'intelligence éclairée par Dieu. Les apôtres, d'autre part, se rapprochent, à plus d'un point de vue, des grands prophètes de vocationn. Paul interprète sa vocation en termes de vocation prophétique. Les grands Apôtres, -nous entendons les Douze et quelques autres témoins officiels de la résurrection,- ont reçu un message comparable à la charge des prophètes de vocation. Comme ceux-ci, ils parlent au nom de Dieu, sont thaumaturges, reçoivent des visions, agissent et s'expriment dans la lumière de l'Esprit" (Le chrétien dans la théologie paulinienne (Lectio divina, 33), Paris 1962, p. 233).

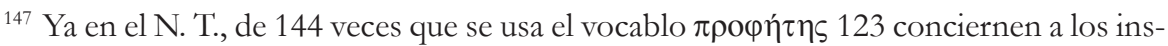
pirados del A.T. y solo 21 a los cristianos, según Cothenet (Prophétisme, 1223). Además aparece dos veces $\pi \rho \circ \varphi \hat{\imath} \imath \varsigma$ : Ana y Jezabel. Pero $\pi \rho \circ \varphi \eta \tau \varepsilon v ́ \omega$ se usa 21 veces

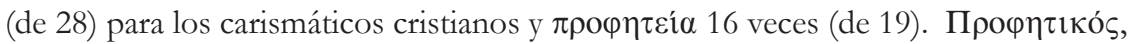
en cambio, sus dos veces se refiere a los oráculos del A. T. Estas proporciones, me pregunto, ¿tenderían ya a corroborar una distinción entre el profetizar cristiano (más amplio) y los pocos cristianos que llegarían a ser llamados 'profetas'? Ciertamente nadie parece haberse directamente autodesignado como tal.

Respecto a los profetas del N. T., anota Aune (Prophecy, 196): "Further, it is noteworthy that the occurrences of the noun $\pi \rho \circ \varphi \eta \tau \eta s$ are almost always in the plural in the NT, while in the Apostolic Fathers the situation is reversed and most occurrences of $\pi \rho \circ \emptyset \eta \tau \eta s$ are singular. This suggests that the prophets were primarily active in groups in the NT era, but as individual practitioners in the postapostolic period".

148 11, 3-6. La jerarquía ignaciana debió ser un golpe fuerte para los itinerantes.

149 Toda Escritura es divinamente inspirada (2Tm 3, 16; cf. 2P 1, 21).

${ }^{150}$ Que un ‘así dice el Señor resucitado’ haya pasado a ser un dicho del Jesús terreno. Las fórmulas de derecho sagrado, cuyo núcleo, según Aune, sería la justicia retributiva, no necesariamente serían proféticas (cf. Prophecy, cap. 9). Aune rechaza la argumentación de Boring y trae las razones de por qué es improbable que los profetas hayan tenido un gran rol en la transmisión y difusión de los dichos de Jesús antes de la formación de los evangelios sinópticos. "We may conclude that the presence of all or many of the features of the pronouncement of sacral law in either the sayings 
of Jesus or in the religious discourse of early Christian writers is not an invariable indication of the presence of prophetic speech" (Ib., 240). "The disappointing conclusion of that discussion was that it was highly doubtful that prophets contributed a great deal of material to the Jesus tradition, and such oracles as they might have contributed would be virtually unrecognizable on the basis of formal criteria" ( $\mathrm{Ib}$., 247). Cf. Hill, op. cit., cap. 7; Cothenet, Prophétisme, 1285s; Aune, Prophecy, 166-168; C. Brown, Prophet, New Intern Dict NT Theol, III, 74-92, pp. 84-86. Aune, analizando las caracteríticas formales de los dichos de Jesús (Prophecy, 163-169), concluye que no son distintivamente proféticas, pero pueden ser usadas en discurso profético.

${ }^{151}$ P. e. Pablo en su comprensión profunda del lugar de Abraham en la historia de salvación o en su interpretación de Hab 2, 4. "The earliest Christian communities, as many recent studies have made clear, expended an enormous amount of effort in establishing a relationship between prophecies and antitypes in the OT and their eschatological fulfilments in the history of Jesus and the formation of the earliest Christian community. Like the Qumran community, the earliest Christians were convinced that they possessed the eschatological gift of the Spirit of God. The Spirit was thought to provide supernatural insight into spiritual matters generally (1 Co. 2 , 6-16; 1 John 2, 21.27) as well as into the true meaning of the words of Jesus (John 2, 22; 12, 16; 14, 26; 16, 12-15) and the OT (Luke 24, 45; 2 Cor. 3, 14-18). In 1 Cor. 2, 6-16 Paul advanced the claim that Christians through the Spirit are enabled to understand the secret and hidden wisdom of God that was concealed for ages but now revealed to those who possess the Spirit of God. The notion of the 'mystery of God hidden for ages but now revealed' has been labeled the 'revelation schema' and occurs elsewhere in Pauline and deutero-Pauline literature (Col. 1, 26-27; Eph. 3, 5.9-10; Rom. 16, 25-26; cf. 2 Tim. 1, 9-10; Tit. 1, 2-3; 1 Pet. 1, 20)" (Aune, Prophecy, 342). Véase Rm 16, 25s.

${ }^{152}$ Es un comentario escatológico (su sentido oculto está siendo cumplido en los días del intérprete) e inspirado (cf. Aune, Prophecy, 339).

153 "While there is not an abundance of evidence that charismatic exegesis was widely practiced in early Christianity, the evidence is sufficiently distributed throughout the NT to indicate that it was indeed widely practised. There is virtually no evidence, however, that this activity was carried out by those who were labeled 'prophets' in early Christianity [...] The negative result of the present inquiry suggests that exegesis of the OT, whether simply eschatological or both charismatic and eschatological, was the primary province of the teacher [...] Because of the early Christian perception that divine revelation was directly available through inspired persons, charismatic exegesis did not and probably could not occupy the central place that it did in the Qumran community [...] The OT continued to occupy a central place in the early Christian quest for divine knowledge" (Ib., 345s). Cothenet afirma, por su parte, a propósito de la interpretación que hace Felipe de Isaías en Hch 8: "Cette découvert progressive du sens de l'Écriture, elle relève d'un véritable charisme prophétique. Il s'agit de lire dans l'événement le rapport avec la Parole de Dieu et d'éclairer par là la route à suivre" (Prophétisme, 1282). Según Hill (op. cit., 100), "at least part of the ministry of prophets in the New Testament was the interpretation of the Old". Según Boring (Continuing Voice, 146): "The evidence of our sources, seen against the Jewish 
background from which early Christian prophecy developed, gives us ample reason for believing that the earliest Christian prophets frequently spoke the word of the risen Lord as a result of their inspired intepretation of the scripture".

${ }^{154}$ Cf. Les prophètes chrétiens comme exégètes charismatiques de l'Écriture, en J. Panagopoulos, Prophetic Vocation in the New Testament and Today (Suppl. N. T. , 45), Leiden 1977, pp. $77-107$.

${ }^{155}$ P. e. $1 \mathrm{Jn} 4$, 1. “These false prophets are analogous to the 'false teachers' of 2 Pet. 2,1 : it is no stated that they laid claim to special visions or revelations, but only that they were spreading a teaching that was contrary to the truth" (Hill, op. cit., 151s).

${ }^{156}$ P. e. véase 2 P 2, 1; Justino, Dial, 82, 1; Ireneo, Adv Haer, III, 16, 8. A propósito del Ap afirma Cothenet: "Comme dans les Pastorales et les Épîtres catholiques, toute distinction s'estompe entre faux prophètes et maitres d'erreur. La polémique traditionnelle contre les premiers sert à lutter contre les partisans d'idées nouvelles [...]" (Prophétisme, 1328; cf. Ib., 1334, a propósito de Justino). Así Ap denuncia a los nicolaítas y a la profetisa Jezabel. El criterio sería doctrinal.

${ }^{157}$ P. e. Did 11, 6. Véase Justino, Dial, 35, 3; PsClemente, Recogn, IV, 34.

${ }^{158}$ Véase Mt 24, 4s.11; Mc 13, 21 spar; Justino, Dial, 82, 2, donde falsos profetas y falsos cristos van muy unidos. Cf. Eusebio, HE, IV, 22, 6. El anticristo de las cartas de Juan (1 Jn 2, 18.22; 4, 3; 2 Jn 7) parece corresponder a los pseudoprofetas de $1 \mathrm{Jn} 4,1$.

${ }^{159}$ Cf. S. Legasse, Prophétisme, Dict Spir, XII, 2410-2434, col 2430-2432. Las advertencias contra los pseudoprofetas enmarcadas en los últimos tiempos, las encontramos en el discurso apocalíptico de Jesús en los sinópticos, etc. Cf. también 1 Jn 4, 1: Ap 16, 13; 19, 20; 20, 10; Did 16, 3s; véase 1 Tm 4, 1s; 2 P 2, 1; 3,3; Jud 18s. Según Cothenet, las advertencias de Jesús en el discurso apocalíptico habrían sido contra el mesianismo celote; en cambio, las de Mt 7, 15 estarían en un contexto catequético (por sus frutos los conocerán) (Prophétisme, 1273-1275).

${ }^{160}$ Marcos el Mago, de quien habla Ireneo (Adv Haer, I, 13, 1-3), inducía a mujeres a profetizar y a través de la unión matrimonial decía que les comunicaba su fuerza, pero no parece haber probado la herejía por el contenido de su profecía.

${ }^{161}$ Según Cothenet, en Hch 13 es difícil distinguir entre profetas y doctores. "La 'paraclèse', qui nous est apparue comme l'une des fonctions du prophète, consiste justement à montrer l'application de la Parole de Dieu dans les circonstances présentes et à en tirer une leçon de courage et d'espérance. Ce long travail de maturation des textes de l'Ancien Testament et de la Parole du Christ, ce fut l'oeuvre et des prophètes et des didascales, si étroitement associés à Antioche (Act., 13, 1) comme dans les communautés pauliniennes. La distinction entre les deux ministères nous semble venir principalement du mode selon lequel ils s'exercent: la prophétie se fait entendre à l'assemblée liturgique, comme une parole d'actualité qui vient de Dieu, tandis que la didaché se transmettait sous forme suivie à ceux qui voulaient avoir une connaissance plus approfondie" (Prophétisme, 1286s, cf. Idem, Prophètes...comme exégètes, 102).

${ }^{162}$ En referencia a Jn dice Cothenet que el Paráclito actúa a la manera de un profeta

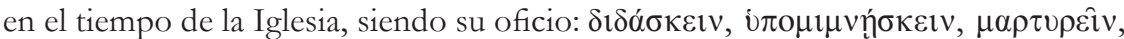




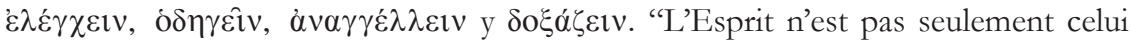
qui soutient la mémoire des disciples, mais [...] celui qui fait revivre les événements et introduit dans leur connaissance plus profonde [...] De même que l'Esprit fait entrer dans l'intelligence des Écritures pour en découvrir la portée christologique (, de même il manifeste toute la signification de l'oeuvre de Jésus" (Prophétisme, 1320). En el proceso contra el mundo, el Paráclito asistirá a los discípulos en el testimonio. Dará el sentido de la historia (Jn 16, 13). "Le charisme prophétique, répandu dans l'Église par l'Esprit [...] remonte en définitive au Christ révélateur du Père” (Ib., 1321) "Ainsi l'Église sera-t-elle toujours assistée par le Paraclet pour la fidèle conservation et explicitation de la Parole du Christ" (Ib., 1322). Según Boring (Continuing Voice, $78 \mathrm{~s}$ ), los profetas cristianos sirvieron como modelo para presentar a Jesús y al $\mathrm{Pa}$ ráclito. El paráclito sucede a Jesús y tiene su mismo rol en la Iglesia pospascual, continuando su voz. "The Johannine understanding of the Spirit and prophecy is analogous to that of Paul, in that the Spirit is given to the community as a whole, an every Christian participates in the life of Spirit and is potentially a prophet" (Ib.). Los extensos discursos joánicos se deben a un largo proceso de predicación, en que actuaron profetas cristianos. El autor de Jn es un maestro inspirado, que maneja la tradición en estilo profético. El mensaje de Jesús debía permanecer atado al Jesús de carne, histórico.

163 “Le livre de l'Apocalypse se présente explicitement comme une prophétie (1, 3; 22, 7.10.18.19) et son auteur comme un prophète $(22,9)$. C'est le 'témoignage de JésusChrist' que Jean a reçu mission de transmettre à l'Église $(1,2)$, contenant une révélation sur "ce qui existe et ce qui doit arriver bientôt" $(1,19)$. On y décèle à la fois les caractères de la littérature apocalyptique, avec ses visions compliquées et l'évocation des temps ultimes, et ceux du message prophétique, avec les jugements de Dieu sur le temps présent, l'appel à la conversion et l'exhortation à tenir bon dans l'épreuve" (Cothenet, Prophétisme, 1322). Hill (op. cit., cap. 3) destaca los elementos proféticos. "Like the prophets, John takes his standpoint in his own day and age and emphasises his contemporaneity with his readers: he offers no review of past history: the period which he interprets is bounded by the death and resurrection of the Lamb and his parousia, when those God-opposing forces which stand behind the actual historical conflict of the Church with a pagan political power will be destroyed. The idea of Heilsgeschichte is the foundation of the view of history which underlies Revelation [...] But if the style and imagery, or some of it, is determined by the apocalyptic tradition, in his interpretation of history and the sensitivity to the actualities of his situation the writer stands in the tradition of prophetic faith and proclamation" (Hill, op. cit., 75). "The prophetic message is founded upon the affirmation of God's decisive, saving action in Christ: this event is the source of the prophet's confidence in the power and victory of God in the present time and throughout the short period of time till the establishement of God's final sovereignty" (Ib., 86). "There is a sense in which all the visions of the future judgment have a fait-accompli aspect, for in the visions they are seen already accomplished. There is thus a combination of 'already' and 'not yet' in the pronouncements of judgment: the whole is cast in a 'not yet' (but soon!) framework, within which there are declarations that judgment is already accomplished" (Il., 86s, citando a Boring). 
164 "There still seem to be some revelation of a second chance of repentance in view of the impending persecution and the imminent return of the Lord (Vis. III, 1, 9). But even if the author does have some personal prophetic experiences, for the most part his writing is a tedious, labored, uninspired and uninspiring work, formally in the prophetic category but written by one for whom prophecy is already a traditional phenomenon that may be stereotyped. In him, we hear the last faint echoes of the 'old prophecy"' (Boring, Prophecy. Early Christian, 501). Aunque el documento en Sim IX, 1, 1 se refiera a lo mostrado por el Espíritu Santo (el Hijo de Dios), quien hablaba bajo la forma de Iglesia; narre visiones y aluda a revelaciones (p. e. en Vis III). Puede verse la comparación entre el profeta del Mand XI y la persona de Hermas, que establece J. Reiling (Hermas and Christian Prophecy. A Study of the Eleventh Mandate (Suppl. N. T., 37), Leiden 1973, cap. 7).

Aune, por su parte, concluye así su análisis: “The results of our inquiry make it probable that al least twelve prophetic oracles have been integrated by Hermas into the final composition of the Shepherd. Thus, in spite of the charge (which is probably not without some basis in fact) that the element of deliberate fiction looms large in the Shepherd, there is a strong probability that a core of prophetic speech has been preserved and elaborated through literary artifice and stylization to produce the finished document known as the Shepherd of Hermas" (Prophecy, 310).

${ }^{165}$ Hermas nunca nombra a los profetas de la comunidad, salvo en el Mand XI, ni los pone como pertenecientes a la estructura de la Iglesia.

${ }^{166}$ Ap 1, 3; 22, 7.10.18s. Véase 1, 1s; 19, 9; 21, 5; 22, 6.16, etc.

${ }^{167}$ 22, 9. Cf. 19, 10. "His (de Juan) special task is that of mediating the revelation of Christ, and this vocation sets him above or at least distinguishes him from his brethren: he is the one by means of whom the others prophets in the Church become sharers in the knowledge and ministry of the divine revelation (Hill, op. cit., 88).

168 10,9-11 (la misión es universal). Véase también 1, 9-20.

169 1, 10. Cf. 4, 2; 17, 3; 21, 10. Según Cothenet, estos '̊v $\pi v \varepsilon u ́ \mu \alpha \tau \imath$ son muy sobrios, distintos a los montanistas (Prophétisme, 1327). Friedrich ve en esos pasajes algunas caracteríticas de experiencia extática, más propias del vidente apocalíptico que del primitivo profeta cristiano. Según Pablo, "der urchristliche Prophet ist ein Mann mit klarem Bewusstsein” (Pr. im Neuen Testament, 852). Comenta Boring (Continuing Voice, 126): 'In Revelation the state of being 'in the Spirit' is an extraordinary state, the state in which things can be seen and heard that are not available to the natural human being, but I would hesitate to describe this state as an ecstatic experience because it is not involuntary but is expressed in terms of the author's own conscious intent, including the reflective use of traditional materials. There is an element of 'ecstasy' in the reception of the revelation in that the seer does genuinely see visions and hear voices, but in the delivery of the message the seer is consciously reflective and intentional, not merely the vehicle for some supernatural power". Esto era diferente al éxtasis en el helenismo.

${ }^{170}$ Cf. también Ap 14, 13; 19, 9; 21,5. Véase 10, 4. Según Aune (Prophecy, 330), “early Christian prophets are only very rarely commissioned to go and tell, while commissions to write are much more frequent". 
${ }^{171}$ Esto es lo más típicamente profético por contenido (p. e. llamado a la conversión) y por forma (Cothenet, Prophétisme., 1325).

${ }^{172}$ Según Aune (Prophecy, 277), "The strongly negative tone of the kind of early Christian parenetic prophecy exhibited in the seven proclamations is occasioned by one important role of Christian prophets: to act as guardians and preservers of Christian behavior, beliefs, and customs".

173 "The weckformel is found only in Rev. 2-3 and 13, 9 within the context of Christian prophetic speech in early Christian literature" (Aune, Prophecy, 278).

${ }^{174}$ Cf. p. e. 22, 6s.10 ( $\left.\pi \rho \circ \varphi \eta \tau \varepsilon i ́ \alpha\right)$.

175 "The visions appear to be a combination of prophetic experience and literary artifice; the task of untangling the two appears hopelessly difficult" (Aune, Prophecy, 275). Boring (Continuing Voice, 80), contra Aune, declara: "It is a misunderstanding of the nature of John's prophetic document to mark off the passages that have explicit prophetic formal characteristics and consider them alone to be prophecy. Rather the book as a whole is a 'revelation of Jesus Christ' [...] Revelation is thus a valuable example of one kind of early Christian prophecy". El profeta cristiano ejerce su función primariamente en el culto comunitario; reinterpreta el A. T. a la luz del acontecimiento de Cristo (Ib., 82). Respecto al cristianismo primitivo, este autor afirma: "Within the community of faith, prophecy was a function of the community gathered for worship" (Ib., 108; véase las pruebas Ib. 107-109). Según Hill (op. cit., 91), "The structure of the Christian prophecy enuntiated in the Revelation is formed by the Old Testament, but between the two stands the saving action of God in Christ's suffering and glorification, and it is this that provides the key to what the old Scriptures say to the contemporary situation".

176 Prophétisme, 1323. "Dans le conflict entre le Monde et Dieu, le Christ intervient donc comme Témoin pour faire triompher la cause de la Vérité" (Ib.). El testimonio de Jesús es idéntico con la voz del Espíritu. "Il (el Espíritu) émane du trône du Père et du Fils, comme l'eau jaillie du Temple (Apoc. 22, 1; cf. Ez., 47, 1 et Joa., 7, 38). Envoyé par le Christ glorifié, il transmet aux disciples 'le témoignage de Jésus' (Apoc., 19, 10) et soutient l'espérance des fidèles dans le retour prochain du Christ"' (Ap 22, 17) (Ib., 1324). Según Ap 1, 5, Jesucristo es el testigo fiel (cf. 3, 14).

177 Véase también Ap 1, 2.9; 12, 17; 19, 10; $20,4$.

${ }^{178}$ Según Boring (Continuing Voice, 150), "like the similar phrase in 1, 1, the genitive construction here seems to have both subjective and objective aspects and may have chosen to express the unique aspect of Christian prophecy in which the risen Christ is both subject and object, both proclaimer and proclaimed".

${ }^{179}$ Tienen poder de cerrar la lluvia del cielo, de transformar el agua en sangre, y de castigar la tierra con numerosas plagas, evocando las figuras de Moisés y Elías.

${ }^{180}$ Cf. Cothenet, Prophétisme, 1329-1331; 1336. Ap 11 introduce la segunda parte del Apocalipsis, la relación de la Iglesia con las naciones. A propósito de Ap 11, 13, comenta nuestro autor: "Nous révèle la double polarité de la vie de l’Église: inutilité apparente de la mission en face d'un monde hostile et puissance conquérante à l'heure où tout semblait perdu" (Ib., 1331). 
181 Afirma Cothenet: “Après avoir dénoncé les périls de l'intérieur (en las cartas), S. Jean dévoile les vraies dimensions du conflit maintenant engagé entre le pouvoir impérial et l'Église [...] Très générale, la vision de l'Apocalypse vise les superstitions et les religions à mystères, qui contrecarraient l'évangélisation et favorisaient l'enracinement du culte impérial. Derrière toutes les formes de syncrétisme, Jean découvre l'intervention de Satan et prédit avec assurance la défaite du Diable, de la Bête impériale et du Faux Prophète (19, 20 et 20, 10)" (Prophétisme, 1329). Y respecto Ap 11, dice: “C'est toute la destinée de l'Église qui nous est présentée ainsi comme un témoignage, soutenu par l'Ésprit de prophétie, témoignage de la victoire de l'Agneau et de son retour prochain [...] Le témoignage prophétique de l'Église est en dépendance directe de la révélation apportée par le Témoin fidèle $(1,5)$, le Verbe de Dieu $(19,13)$ " (Ib., 1331). "All the members of the church are, in principle or potentially, prophets, just as the whole Church presents itself, in exemplary fashion, in the form of the 'two witnesses' (11, 3ff.)", es lo que estaría implicado según Hill (op. cit. 90).

${ }^{182}$ Es el tiempo de la recompensa para sus siervos los profetas, para los santos y para todos los que temen su nombre (Ap 11, 18). Con la caída de Babilonia se regocijan los santos, los apóstoles y los profetas (Ap 18, 20). Cf. 16, 6; 18, 24 (sangre de los profetas). Véase Mt 23, 34spar.

${ }^{183}$ Ap 22, 18s. Cf.1, 3; 22, 7.10. Según Aune (Prophecy, 275), "John intended the Apocalypse to be read aloud in a service of worship $(1,3 ; 22,18)$, and it is very possible that this public reading would replace a prophetic address to the congregations by one or more of their local prophets." "The book contains worship materials such as the doxology of 1, 5b-6 and the hymns of 4, 11 and 5, 9b-10: and descriptions of worship in the heavenly sphere abound (chs 4-5; 7, 9-17; 15, 1-4; 19, 1-5). The allusions to Christian believers as 'priests' $(1,6 ; 5,10 ; 20,6)$ serve to strengthen the impression that the Revelation is a worship-oriented book, written not for private reading but for public declaration (by the prophets, perhaps) in congregational worship" (Hill, op. cit., 90).

184 "Der jüdischen Prophetie am nächsten steht in dieser Hinsicht der Prophet der Johannesapokalypse. Bei ihm kommt eine Prüfung seiner Aussagen auf ihre Richtigkeit in keiner Weise in Betracht, weil sie von höchter Stelle, von Gott selbst, als zuverlässig und wahr legitimiert worden sind Apk 21, 5; 22, 6" (Friedrich, Pr. im Neuen Testament, 851).

${ }^{185}$ En el Espíritu, espirituales. Dice J. P. Audet comentando Did 10, 7: “Pour peu qu’on y songe, du reste, on n'a pas de peine à reconnaitre que le rapport spécial du prophète a la 'bénédiction' devait simplement résulter de la nature des choses. La 'bénédiction' étant regardée comme la plus haute forme cultuelle revêtue par la parole, elle revenait de droit, pour ainsi dire, à ceux que l'Esprit comblait de l'admiration et de la joie des 'oeuvres' de Dieu et à qui il donnait en même temps les moyens pour le dire (op. cit., 433). En referencias a textos como Hch 13, 1-3; 1Ts 5, 17-20; 1 Co 11, 5; 14, 13-19, concluye Friedrich: "Prophetie und Gebet sind nicht dasselbe. Sie gehören aber aufs engste zusammen” (Pr. im Neuen Testament, 854).

186 "Dans son ensemble, l'Apocalypse se caractérise par le grand nombre d'hymnes et de bénédictions qui s'insèrent au milieu des visions" (Cothenet, Prophétisme, 1328). 
"The writer of the Apocalypse used hymnic liturgical materials as they were used by prophets in the worship of the Christian community: to realize in the present realities otherwise apprehended only as future eschatological events" (Aune, Prophecy, 298, citando a Thompson).

${ }^{187}$ Cf. Aune, Prophecy, 296.

${ }^{188}$ P.e. 6, 1s.7; 14, 8;16, 5-7. Véase también 12, 1s; 18, 15; 26, 2s.10, que, entre otros pasajes, también revelan conciencia de inspiración.

189 "The Odes contain a number of problematic passages where it appears that the speaker is Christ (8, 8-19; 10, 4-6; 17, 6-16; 22, 1-12; 28, 9-20; 31, 6-13; 36, 3-8; 41, 8-10; 42, 3-20)" (Aune, Prophecy, 297).

190 "El Señor ha dirigido mi boca con su palabra y ha abierto mi corazón con su luz. Él ha hecho habitar en mí su vida inmortal y me ha concedido proclamar el fruto de su paz para convertir las almas de los que quieren venir a Él, y para capturarlos en un hermoso cautiverio hacia su libertad." (trad. de A. Piñero en A. Díez Macho y A. Piñero Sáenz, Apócrifos del Antiguo Testamento, III, p. 101s). Cf. 6, 13-18; 12, 1-4.

${ }^{191}$ Aune habla de los Himmelsreise del odista (cf. 11, 1-21; 21, 1-7; 36, 1-8; 38, 1-21) (Prophecy, 297s). Se desarrollan dentro de una escatología realizada, que penetra todas las Odas. Od 7, 16-20 se referiría a una teofanía escatológica, donde se cantará con el arpa de muchos tonos.

192 "Although the Odes do not easily surrender their secrets, it appears that they are best regarded as a distinctive type of prophetic hymnbook which, while it has connections with other types of early Christian prophetic speech, nevertheless remains unique" (Prophecy, 199).

${ }^{193}$ Fil 7. "The loud voice indicates a state of excitation or possession trance and is a frequent accompaniment of oracular speech" (Ib., 292).

${ }^{194}$ Cf. p. e., H. O. Maier, The Charismatic Authority of Ignatius of Antioch: A Sociological Analysis, TheolDigest 37 (1990) 235-240.

195 Tral 5, 1s.

${ }^{196}$ Ef 20, 2.

${ }^{197}$ Cf. Rom 8, 2.

${ }^{198} \operatorname{Rom} 7,2$.

${ }^{199}$ Mart Pol 16, 2 (cf. 5, 2; 12, 3). Toda palabra que salió de su boca se ha cumplido o se cumplirá.

${ }^{200}$ Cf. Justino, Dial, 39, 2; 82, 1; 87,56-88, 1 (cf. 76, 5); Ireneo, Adv Haer, II, 32, 4; III, 11, 9; V, 6, 1; Epid, 99. Véase Tertuliano, Adv Marc, V, 8, 4-9, 1; Eusebio, HE, V, 3, 4; 17, 2.4; Bern, 16, 9s. Por otro lado, el uso que hace de la profecía (Espíritu profético), p. e. Justino en su apologética contra judíos y paganos, muestra el gran peso que esta tenía en el mundo antiguo. Respecto al testimonio de Ireneo, concluye R. Polanco Fermandois: "Para finalizar, resumamos brevemente lo dicho sobre la profecía en la Iglesia. Frente a sus adversarios -que de diversas maneras ponían en cuestión la 
existencia de una verdadera profecía neotestamentaria- a Ireneo le interesaba destacar la real presencia de carismas proféticos hoy en la Iglesia. Sin embargo, la atención principal del Lugdunense se orietaba a señalar más específicamente que la profecía era fruto de la presencia del Espíritu Paráclito en la Comunidad cristiana, el cual había sido derramado en Pentecostés y permanece en todos los bautizados" (El concepto de profecía en la teología de san Ireneo (BAC), Madrid 1999, p. 385).

${ }^{201}$ Cf. Eusebio, HE, V, 17, 2 -4 (véase III, 37, 1). Según Asc Is 3, 26-28 habría pocos profetas en esa época, en contraste con la época anterior (cf. 3, 19s). Véase Orígenes, C Celso, I, 46; VII, 8; Sibila, I, 385s. "Irgendwo in der grossen Kirche gibt es Geistesgaben, aber hervorragende Vertreter, die den Titel " $\pi \rho \circ \varphi \eta \dot{\tau \eta \varsigma " ~ v e r d i e n t e n, ~ w e r d e n, ~}$ soweit ich sehe, seit Polykarp, der als “ảvì $\alpha$ à (Smyrn. 16, 2), nicht mehr genannt” (Fascher, op. cit., 221).

Según Panagopoulos (Die urchristliche Prophetie, 9), la Iglesia no estaba interesada en

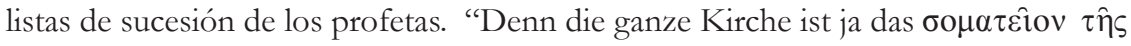

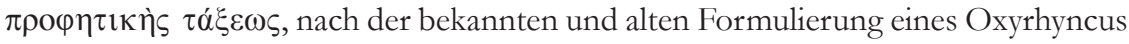
Papyrus (Oxyrhynchus Papyri I, London 1898, V, 8f)" (Ib). "Although the notion of a 'prophetic succession' was already known in Judaism, it first appears in early Christianity toward the end of the second century in Montanism and in anti-Montanism polemic" (Aune, Prophecy, 203).

202 "Der Montanismus war das letzte grosse Aufflakern der Prophetie in der Kirche. Mit siener Bekämpfung und mit seinem Auscheiden hat das institutionelle Amt einen entscheidenden Sieg über das Charisma errungen" (Friedrich, Pr. in der alten Kirche, 863). Puede verse, entre otros, H. F. von Campenhausen, Kirchliches Amt und geistliche Vollmacht in den ersten drei Jahrbunderten (Beiträge zur historischen Theologie, 14), Tübingen 1963, $2^{\mathrm{a}}$ ed., 198-210.

203 Montanism. Gender, Authority and the New Prophecy, Cambridge 2002, 26-45.

204 Aune (Prophecy, 313) afirma por su parte: "In general, Montanism should be viewed as a renewal movement within the second-century church; more specifically it was a millenarian movement similar to the many millenarian movements in early Judaism including that of Jesus himself [...] Their acceptance of the value of martyrdom and emphasis on a rigorous ethical position tended to place distance between them and non-Montanist Christians". Puede verse G. Buschmann, Martyrium Policarpi 4 und der Montanismus, VC 49 (1995) 105-145. "Si alimenta delle antiche tradizioni profetiche e apocalittiche. Lo scopo è ravvivare e restaurare, con il ricorso all'autorità del Paraclito, l'antica situazione della chiesa: efficacia dello Spirito, parlare in lingue, attesa degli ultimi tempi, etica rigorosa" (V. Saxer, Montano-Montanismo, DPAC, 22992301, col. 2300). "I tratti più caratteristici sono anzitutto la glossolalia e un linguaggio spirituale tendente all'estasi e all'entusiasmo. Tanto Montano quanto Prisc(ill)a e Massimilla (ma nessun altro) pretendono di essere la voce di Cristo e dello Spirito santo. Essi parlano perciò sull'autorità di questo Spirito ed esigono fede incondizionata e assoluta ubbidienza ai loro ordini. Essi negano ogni autorità ecclesiastica. Contenuto della loro profezia è l'annuncio dell'imminente fine del mondo, che Massimilla pronostica per il tempo immediatamente successivo alla propria morte. Le guerre scoppiate sotto Marco Aurelio sono interpretate come segni premonitori. 
Come preparazione alla fine sono prescritti una morale rigorosamente ascetica, con il divieto del matrimonio (in seguito soltando delle seconde nozze), digiuni severi, consistenti elemosine di ogni specie; è incoraggiato il martirio, è proibito sottrarsi alle persecuzioni. In riferimento ad $A p 21,1.10$, la Nuova Gerusalemme, discesa dal cielo, dovrà localizzarsi a Pepuza o a Timione (Frigia). I credenti dovranno farsi trovare lì all'arrivo del Signore. Nessuna posizione ereticale viene però asunta sul piano dogmatico: si resta sul terreno dell'ortodossia” (Ib., 2299).

${ }^{205}$ Op. cit., 188-190. "Fondamentalement, la 'nouvelle Prophétie' est d'abord un renouveau spirituel à coloration apocalyptique et même encratiste, non sans quelque parenté avec certaines idées gnostiques" (F. Blanchetière, Le montanisme originel, RevSR 52 (1978) 118-134; 53 (1979) 1-22, p. 19). Según Cothenet (Prophétisme, 1334), el montanismo es un desarrollo del cristianismo asiata, es una renovación de la profecía apocalíptica en la Iglesia.

206 "Moreover, the glorification of Pepuza as the New Jerusalem was a threat to all the ancient sees, and, what is even more important, just when the formation of a defined canon of Scripture seemed the right way to check Gnosticism, the Montanisms were teaching men to expect new and authoritative revelations" (Hill, op. cit., 189).

${ }^{207}$ P. e. Eusebio, HE, V, 16, 9s. Según Panagopoulos (Die urchristliche Prophetie, 15), "Nicht die Prophetie als solche wurde also bekämpft, sondern ihre Loslösung von der Kirche. Gerade in dieser Frage entscheidet sich der wahre Charakter der Prophetie".

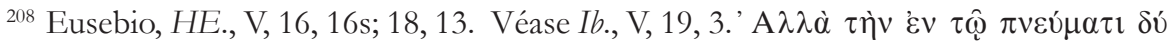

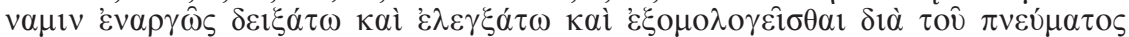

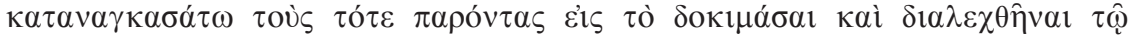
$\pi v \varepsilon v ́ \mu \alpha \tau 1 ~ \lambda \alpha \lambda o \hat{v} \tau \tau$... (Eusebio, HE, V, 16, 17). ¿Era esto un desafío pneumático al estilo de Hermas, Mand XI, 14s? Según Trevett (op. cit. 157), "Exorcism here should be seen not least as an attempt at social control" (el descrédito de tratarla como endemoniada, etc.).

También se les objetará, según las fuentes de Eusebio y Epifanio, alguna profecía no cumplida (Eusebio, HE, V, 16, 18s; Epifanio, Panarion, 48, 2, 6s), no tener ya profeta después de Maximila (Eusebio, HE, V, 17, 4; Epifanio, Panarion, 48, 2, 1); aceptar dones (Eusebio, HE, V, 18, 4.7), y diversos malos comportamientos.

${ }^{209}$ Véase p. e. Eusebio, HE, V, 16, 7s.9; V, 17, 1-3 (comenzaba por una à $\mu \alpha \theta i ́ \alpha$ voluntaria); Epifanio, Panarion, 48, 3ss. P. de Labriolle (La crise, p. e. p. 171), después de aludir a probables rarezas irracionales del éxtasis montanista, opina que ciertas manifestaciones de este tendrían una real semejanza con la glosolalia paulina. ¿Revelaría este éxtasis influencia pagana? Aune (Prophecy, 313) cree que no: "All the major features of early Montanism, including the behavior associated with possession trance, are derived from early Christianity. Montanism is particularly closely associated with the Gospel of John and the Apocalypse of John; their emphasis on the Paraclete was drawn from the former, and their preoccupation with the New Jerusalem (which was expected to appear in Pepuza) was gleaned from the latter)". Boring (Continuing Voice, 128), por su parte, concluye: "Our sources never describe prophecy in ecstatic terms. Since this was also generally the case in that Judaism from which early Chris- 
tianity sprang". Esto en contraposición a la típica concepción helenista. Tertuliano alude a una hermana que tiene revelaciones en éxtasis (De anima, 9, 4, CCh II, 792s).

"Was die falsche Ekstase der Montanisten von der kirchlichen Prophetie unterscheidet, ist für den Anonymus zum einen die willentliche Herbeiführung dieses Zustandes (im unterschied zur göttlichen Initiative bei wahrer Ekstase...), zum andern die offentsichtlich

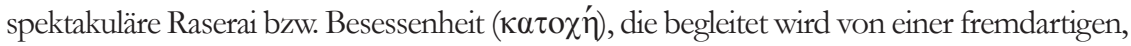

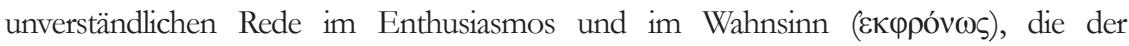

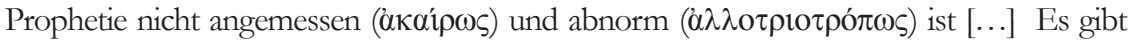
mehrere zeitgenössische Zeugnisse dafür, dass spektakuläre Ekstase dieser Art als ein Charakteristikum der Gallen und verwandter Vertreter des paganen Wanderpriestertum galt" (G. Schöllgen, Der Niedergang des Prophetentums in der Alten Kirche, JBTh 14 (1999) 97116, 113). Véase Orígenes, C Cels, VII, 3.9ss.

210 "La conception grecque de l'enthousiasmos, selon laquelle l'inspiré est un instrument purement passif et inconscient du pneuma divin, Philon l'avait utilisé pour rendre compte de l'inspiration biblique, S. Paul se refuse à s'engager dans cette voie... La grandeur du prophète, c'est qu'il est à la fois en contact avec Dieu, puisque son noûs reçoit l'illumination divine, et avec les honmmes, puisqu'il transmet un langange intelligible" (Cothenet, Prophétisme, 1296).

${ }^{211}$ Oráculo 12, según la numeración de K. Aland, Bemerkungen zum Montanismus und zur früchristlichen Eschatologie, en Kirchengeschichtliche Entwürfe, Gütersloh 1960, 105-148, p. 145; 11 en la numeración de R. E. Heine, The Montanist Oracles and Testimonia (Patristic Monograph Series, 14), Macon G.A, 1989, p. 5). Pero Trevett (op. cit., 96) afirma al respecto: "The $\hat{\omega} \delta \varepsilon$ of Pan. xlix, 1 is unclear. The apparition may have indicated, on the one hand, that here (Pepuza) will Jerusalem descend from heaven. On the other hand it may be thus, i.e. that the Christ figure itself is representative of that descent 0. In addition the present infinitive may indicate either 'comes down' or 'will come down' in this context".

212 "La thèse de Montan selon lequel l'ère du Paraclet succède à ère du Fils contredit l'enseignement du IVe Évangile" (Cothenet, Prophétisme, 1334). Después de Maximilla, quien se cree enviada como intérprete de la Alianza, vendrá la consumación (or. 13 y 15 en Aland, 6 y 8 en Heine) Si la Iglesia perdona los pecados, Dios no, no sea que vuelvan a pecar. (or. 7 en Aland, 12 en Heine).

${ }^{213}$ Véase p. e. Hipólito, Philos, VIII, 19, 1s. En la polémica posterior, como leemos en los testimonios de Heine (op. cit.), los montanistas argüirán que Montano y sus profetisas recibieron el Espíritu (Paráclito) en plenitud y no parcialmente (1 Co 13, 8-10), como Pablo y los apóstoles que solo recibieron la promesa, las arras. Por eso que Pablo permitió las segundas nupcias.

214 "If the Prophecy did not differ from catholic practice in essentials, if it did not put itself at odds with the spirit of the Scriptures (though there was room for disagreement about how they were to be interpreted, of course), then where was the problem? The problem was that the Spirit-Paraclete demanded the last word on all subjects... If the assumptions of the Prophecy about revelation prevailed, then catholic clergy no longer had the final word on matters of orthopraxis" (op. cit., 120). "In many respects there was little to separate the Prophets from their catholic co- 
religionists. Difference were mostly differences of degree. Theological orthodoxy was not at stake and both sides appealed to the same Christian writings. There was the matter of exposition of those Christian writings of course, but the threat was not that an enlarged or parallel 'canon' of writings was being created (for no such canon had been finalised). Nevertheless, the Prophets claimed direct authority of the Spirit (which clarified the meaning of Scripture) and that might prove at odds with the teaching authority of the catholic clergy. Novelties of discipline challenged catholic orthopraxis and robbed catholic teachers of the initiative in such matters [...] Authority was at stake. A potentially successful Prophecy could not be allowed to flourish, and in Asia Minor objections to ecstasy, to inappropriate behaviour and the personal failings of the Three (es decir, Montano, Priscila y Maximila) (in the absence of anything weightier) provided grounds for condemnation" (Ib., 146). La autora ha ido limando las diferencias. No habría, en los comienzos, una ardiente espera milenarista inminente, ni un descenso de la Jerusalén celestial, ni un mayor influjo pagano en Frigia, etc. La acusación de modalismo surge en Roma y no afectará a todos (como podemos ver en Heine, op. cit., la polémica posterior se basará mucho en el oráculo 1 de la lista de K. Aland, 15 de Heine). Antes había expresado Trevett: "Both sides had valued the same kinds of writings; both sides acknowledged the rightness of the two fold basis for Christianity's growth -i.e. apostolic and prophetic work (Eph. 2, 20). But in the Prophetic-catholic clash we see 'apostolic' increasingly being set over against 'prophetic' and given greater weight by the catholic side. The Prophets made appeal to prophetic succession, the catholic side laid increasing weight on apostolic succession and writings of time past, thus invalidating any allegedly new insights" (Ib., 136). Trevett también había dicho respecto al montanismo: "It was claiming (via the prophetic work of the Paraclete) to bring something new and would not allow the catholic side, in any case, to lay claim to a monopoly of insight about what 'apostolic' tradition entailed" (Ib., 54). Respecto a la reacción romana llegará a afirmar: "However, contemporary prophecy was being denied in Rome 0. Heine is surely right to think that the Roman church 'did not argue with the Montanists about true or false prophecy', nor about rational versus ecstatic prophecy. It refused simply to grant the possibility of any prophecy after the Apostles" (Ib., 65). Según ya había afirmado Labriolle (La crise, p. e. 131ss), el gran escándalo de Montano era que revelaba cosas nuevas ('nueva profecía').

${ }^{215}$ P. e. Policarpo, Perpetua.

${ }^{216}$ Cf. Prophétisme, 1335.

${ }^{217}$ XXV, 47; cf. De util credendi, XVI, 34.

${ }^{218}$ Con todo, Agustín viejo abrirá un archivo para ir anotando los milagros que se producían (cf. F. Van Der Meer, Saint Augustin pasteur d'âmes, II, Colmar-Paris 1955, pp. 386ss).

${ }^{219}$ Cf. p. e. 1 Ts 5, 19-21; 1 Co 12, 10; 14, 29. La falsa profecía incide en el descrédito de esta (cf. p. e. Zac 13, 2-6).

${ }^{220}$ Aune (Prophecy, 87s) hace la siguiente presentación de Crenshaw respecto al A. T.: "In a recent study of prophetic conflict and its effect upon Israelite religion, J. L. Crenshaw has synthesized the criteria used in the OT for identifying and exposing 
false prophets and their lying oracles (Prophetic Conflict, Berlin 1971 , pp. 39-61). He has sorted the criteria into three major categories and provided each subpoint with a short critique: 1) Message-centered criteria: a) If the prophetic prediction is not fulfilled, the prophet is false (Deut. 18, 22; 1 Kgs. 22, 28; Isa. 30, 8). The problems with this criterion are the general nature of many prophetic oracles (making the perception of their fulfilment difficult), the condicional nature of prophecy, and the limited application of this criterion only to predictive prophecy. b) True prophets prophesy judgment, while false prophets promise salvation (Jer. 28, 8; 1 Kgs. 22; Ezek. 13, 10). This criterion is made problematic by the juxtaposition of promises of salvation and judgment in the same prophet. c) False prophets receive their messages through dreams rather than visions (Jer. 23, 25-28). Dreams, however, were not looked upon unfavorably in the OT (). d) Allegiance to Yahweh was the mark of a true prophet, while allegiance to Baal the mark of a false prophet (Deut. 13, 1-3; cf. Jer. 2, 8.26-27; 23, 13; 32, 32-35). These 'false' prophets, however, served Baal while believing themselves to be devotees of Yahweh in an alternate name and form. 2) Criteria focusing on the man: a) The false prophet was a professional cult official. However, cult prophet were frequently faithful to the word of Yahweh. b) False prophets were characterized by immoral conduct (Jer. 3, 11; 23, 14; Isa. 28, 7). However, Hosea's conduct is at least open to question. c) The true prophet was conscious of a divine commission (Amos 7, 10-17; Mic. 3, 8). Yet this claim was challenged (Jer. 23, 21.32; 43, 2-3) and was difficult to substantiate. 3) Chronological criterion: Prophets not belonging to the period from Moses to Ezra were false prophets. However, this standard contributes nothing to the discernment of false prophecy within the OT itself. In sum, Crenshaw contends that no criterion proved adequate for distinguishing true from false prophecy, and that the rise of false prophecy was inevitable and resulted in the general decline of prophecy, since there was no absolutely reliable way to validate the credentials of the divine messenger. Conflicting claims by prophets, he maintains, ultimately resulted in a total loss of prophetic credibility; people turned instead to wisdom and apocalyptic". Cf. W. Vogels, Comment discerner le prophète authentique?, NRT 99 (1977) 681-701; Boring, Continuing Voice, 105s.

${ }^{221}$ Cf. Dt 13, 2-6.

2221 Jn 2, 22; 4, 1-3 (véase también 1 Jn 5, 6, etc.); 2 Jn 7 . Hay que permanecer en lo oído desde el principio (cf. $1 \mathrm{Jn}$ 2, 24). Cf. Cothenet, Prophétisme, 1318s ("pour la fidèle transmission de la foi, Jean fait confiance à l'action de l'Esprit": 1 Jn 2, 20.27; 5, 6). Cf. Did 11, 1s, que sería norma para todo misionero. A Jezabel también se le aplicaría un criterio doctrinal (Ap 2, 20ss).

${ }^{223} 1$ Co 12, 3. Rm 12, 6 puede interpretarse como en armonía con la fe la Iglesia. Cf. Ga 1, 8s; 2, 2. "The most important informal criterion set forth by Paul for the judgment of prophetic speech, or indeed viewpoints expressed through a variety of oral and written forms of communication, was the content of the message. Such messages must be in agreement with what Paul himself had previously taught (2 Thess. 2, 1-3; Gal. 1, 8-9), or with the generally accepted beliefs and customs of the Christian community (1 Cor. 12, 1-3)" (Aune, Prophecy, 222). Hill (op. cit., 119) respecto a Rm 12, 6 , expresa "'What Paul is saying, then, is that the person who exercises the gift of prophecy should speak only when conscious of his words as inspired, and presumably only for as long as he is confident that God is speaking through him". 
${ }^{224}$ Tiene que haber coherencia con la fe recibida. "Das erste und entscheidende Kriterium war natürlich das Verhältnis der prophetischen Verkündigung zur Wahrheit, näherhin zum evangelischen Dogma" (H. Bacht, Wahres und falsches Prophetentum. Ein kritischer Beitrag zur religionsgeschichtlichen Behandlung des frühen Christentums, Bibl 32 (1951) 237-262, p. 260).

${ }^{225}$ Véasese también p. e. 1 R 22, 28; Hch 11, 28.

${ }^{226} \mathrm{Jr} 28,8$ s, contra Jananías.

227 "Presupone la lectura de la historia con espíritu profético" (A. González, Verdaderosy falsos profetas, en: A. González, N. Lohfink, G. von Rad, Profetas verdaderos. Profetas falsos, Salamanca 1976, 13-76, p. 49). Según Hermas, Mand XI, 3, el diablo dice algunas cosas verdaderas a través del falso profeta tratando de derribar a alguno de los justos.

${ }^{228}$ Cf. Mt 7, 15-23par; 12, 33-35par. Véase Ev Th, 45.

${ }^{229}$ Cf. 1 Ts 5, 19-21. Véase 1 Jn 4, 1.6.

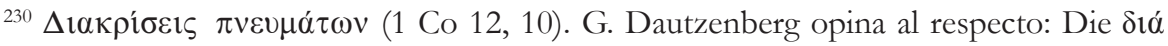

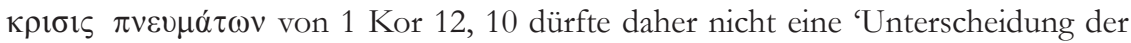
Geister' meinen, sondern die charismatische Deutung von Geistesoffenbarungen”

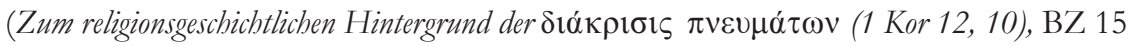
(1971) 93-104, p. 104; cf. Idem, Prophetie bei Paulus, 66-68).

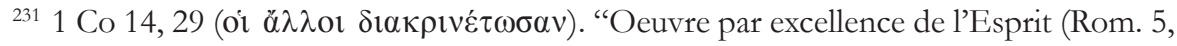
5), l'agapè est le signe qui permet de discerner celui que est authentiquement mû par Dieu" (Cothenet, Prophétisme, 1298). La profecía pasará; el à $\gamma \alpha \dot{\pi} \eta$, no. "La prophétie est limitée par la 'mesure de la foi' que Dieu nous accorde (Rom., 12, 3)" (Cothenet, Prophétisme, 1294). Véase 1 Co 12, 31-13, 2. "Ne peut être un message de Dieu la parole qui ne s'accorde pas avec l'unique fondement (cf. 1 Co, 3, 11)). Ne peut provenir du 'Dieu de paix' (1 Co 14, 33) le messsage qui suscite le trouble dans la communauté ou tend à isoler une Église locale dans une orgueilleuse suffissance" (Cothenet, Prophétisme et ministère, 43; cf. 1 Co 14, 36ss). "Nous voudrions mettre en valeur l'importance de la koinônia, à savoir l'attachement à la communauté de foi et d'agapè que constitue l'Église, comme critère de discernement' (Cothenet, Ib., 48). "Mit den 'Weg über alle Wege' hat Paulus das entscheidende Kriterium expliziert, von dem sich auch der christliche Gottesdienst angemessen in den Blick nehmen lässt" (W, Schrage, Der erste Brief an die Korinther, III (1 Kor 11, 17-14, 40) (EKK), Neukirchen-Vluyn 1999, 376).

${ }^{232}$ Cf. 11, 3-12.

${ }^{233}$ Puede verse Reiling, op. cit., cap. 3.

${ }^{234}$ Véase también Ireneo, Adv Haer, I, 13, 4.

${ }^{235}$ Se parecen a paganos que consultan un adivino (cf. p. e. Reiling, op.-cit., cap. 4). Así, según Lc 6, 26, se habla bien de los pseudoprofetas. Respecto al profeta verdadero, puede verse la máxima de Mc 6, 4par (cf. Mt 5, 11spar) y el tema de la persecución del profeta.

${ }^{236}$ Véase también Mad VI, 2, 1-5, etc. 
${ }^{237}$ A este respecto afirma Reiling (op. cit., 72): "Only the Spirit itself is able to carry

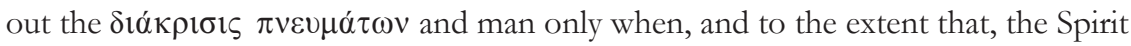
speaks and works through him. Such a man may rightly be called $\pi v \varepsilon v \mu \alpha \tau 1 \kappa o ́ s$, and when he is truly a Spirit-man, he is at the same time not subject to the control of other people who do not have the Spirit to the extent he has it. Hence o $\pi v \varepsilon v \mu \alpha \tau \imath \kappa o ̀ s$

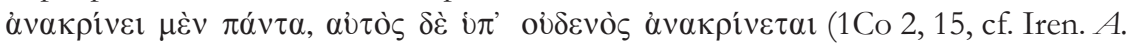
$H$. IV 33,1). The only one to test him is another $\pi v \varepsilon v \mu \alpha \tau 1 \kappa o ́ s$ or a community of $\pi v \varepsilon v \mu \alpha \tau \iota \kappa o ́$. This is precisely the situation in Hermas".

Quizás podríamos también llamarlo de resonancia, de armonía. ¿'Tiene esta confrontación algo que ver con la exigencia a la profetisa montanista Maximina, de somerterse a un exorcismo? Véase también Eusebio, HE, V, 16, 17; Firmiliano de Cesarea, Ep, 75, 10 (en Cipriano). Cf. además Hch 13, 8-11; 16, 16-18; 19, 13-17. La armonía también aparece en las reglas de discernimiento de Ignacio de Loyola (p. e. EE, 335).

Vogels, por su parte y después de mostrar la relatividad práctica de los diversos criterios, concluirá remitiendo, por así decirlo, al profeta que hay en cada cristiano. "Au terme de notre enquête sur l'existence et la valeur des critères permettant de discerner les 'vrais' des 'faux' prophètes, la réponse est bien un 'oui [...] mais'. Les critères proposés ont une certaine valeur, mais par ailleurs ils posent tant de problèmes que pratiquement on n'est pas plus avancé $[\ldots]$ Ce qui revient à remettre à l'histoire le verdict qui détermine le 'vrai' prophète. Jérémie a subi le test avec succès, l'histoire a donné la raison à Jérémie et non à Hananya. D’une certaine façon on est ramené au critère de la réalisation de la prophétie, non plus cependant dans le sens restreint selon lequel on considère telle ou telle prédiction, mais dans une acception très large. Le prophète a accompli sa mission. Il a interpellé les hommes et continue à les interpeller. Que doivent faire alors les contemporains des prophètes, pour lesquels le jugement de l'histoire n'est pas encore prononcé? En dernière analyse chacun est renvoyé à son jugement personnel, à sa propre conscience, à travers laquelle Dieu parle, mais d'une voix qui est mystérieuse. En un certains sense il y a un 'prophète' en chacun de nous [...] On pourrait dire peut-être qu'il faut être prophète pour discerner le prophète, 'car à tout homme qui a, l'on donnera' (Mt 25, 29) [...]. En cette période où les fruits ont enconre à mûrir en attendant le jugement de l'histoire, où nous ne marchons pas encore dans la certitude, il y a un critère qui ne ment jamais, celui de la charité. Et la charité n'est pas division, mais unité” (Vogels, op. cit., 698ss). A. González, por su lado, afirma: "Por eso tienen todos un principio de discernimiento de los espíritus o una luz interior para distinguir a los profetas. Se puede dar otro nombre a esa luz: el sensus fidei o la antena sensible de la fe que señala lo que viene de Dios y lleva a él, por la comunidad, y acusa lo que, por venir de otro espíritu, destruye el pueblo de Dios" (op. cit, 73).

238 "Here the false prophet, full of the empty spirit of the devil, is in effect exorcised and left empty and speechless through the power of the holy spirit that is present" (C. Osiek, Shepherd of Hermas. A Commentary (Hermeneia. A Critical and Historical Commentary on the Bible), Augsburg Fortress, Minneapolis 1999, p. 146). El falso profeta se dirige a los hombre vanos (vacíos) con los que armoniza. El También busca los primeros puestos, etc. Que los profetas sean, pues, probados (бокí $\mu \alpha \zeta \varepsilon$ ) por sus actos y su vida. 
${ }^{239}$ Cf.p. e. Am 7, 14s; Is 6; Jr 1, 4ss. Véase Aune, Prophecy, 97-99. El relato de la vocación de Pablo se repite tres veces en Hch.

${ }^{240}$ Por su parte, Ignacio de Loyola, de acuerdo a la herencia de la tradición espiritual y según su experiencia personal, en sus Ejercicios proporcionará un método de discernimiento de la voluntad de Dios, que puede llegar a ser suficientemente claro. Pero esto requiere un camino bajo la gracia: una fuerte ascesis previa contra todo desorden dentro del marco de una conversión (indiferencia verdadera para buscar los mejores medios de servir a Dios), una contemplación de Cristo a fondo con gran deseo y voluntad de seguirlo. Y que lo elegido se pruebe en un tiempo de la confirmación. Todo esto en diálogo con un acompañante eclesial, etc.

Quizás podemos sintetizar algunos criterios de discernimiento, que han aparecido a lo largo de este trabajo y que deben confluir, en los siguientes puntos: doctrina sana y no ser irracional; cumplimiento del futuro profetizado, sobre todo si es de paz y prosperidad; la vida del profeta y su forma de profetizar; la armonía con los espirituales y su final recepción por la Iglesia. 'Armonía' es una palabra clave y esta se juega también en la confirmación y recepción.

241 "Wenn sich dieses Scheitern der Prophetie schon zur Zeit des Paulus abzeichnet, ist nach seinen Gründen zu fragen. Mir scheint, dass die Hauptschwierigkeiten zur Zeit des Paulus auf den unterschiedlichen Traditionsvoraussetzungen von Judenund Heidenchristen beruhten. Heidenchristliche Gemeinden wie die von Thessalonike und Korinth konnten die im Judenchristentum unter Aufnahme apokalyptischer Voraussetzungen entwickelte Prophetie nur schwer verstehen schätzen und ausüben" (Dautzenberg, Botschaft, 158; cf. Id., Urchristliche Prophetie. Ihre Erforschung, ibre Voraussetzungen im Judentum und ibre Struktur im ersten Korintherbrief (BWANT VI, 4 (104)), Stuttgart, Berlin, Köln, Mainz 1975, p. 299s).

${ }^{242}$ Hill, en cierta posición intermedia entre Käsemann y Campenhausen, concluye así: "Although the dogma that there are Christian prophets survived rather longer than prophecy itself, the repudiation of Montanism marks the effective end of prophecy in the Church. Its disappearance was due, in the main, to two factors [...] The number of people possessing prophetic powers grew less and less (cf. Did. 13, 4) -perhaps with the waning of the imminent expectation of the End- and appointed office-bearers and Scripture took the place of pneumatic inspiration [...] Consequently, when the era of the prophets closed, with the condemnation of Montanist enthusiasm and ecstasy, the increasing hellenisation of the Church -with its emphasis on the spirituality and rationality of the faith-created the tendency to rely more and more on rational and didactic forms of spiritual utterance: therefore the place of the prophets, as witnesses to the living truth, was taken by the 'teachers' of both the free and the official Church, thast is, by catechists, preachers, scholars and theologians (e.g. Clement of Alexandria), men who were the first conscious champions of an individualist and personal spirituality in the Church, but whose authority was based not on any revelation directly received but on the exposition of existing traditions, and very particularly of the Scriptures, at first those of the Old Covenant, but later those of the New and of the Apostles [...] The other main reason for the decline of prophecy was that false prophets were present -from a quite early stage in the Church's life (cf. 1 John and the Pastoral epistles) and in growing numbers in 
the second and third generations (cf. the Didache and Hermas)- and these undermined the position and authority of genuine prophets." (op. cit., 190s). M. Dibelius, a propósito de la Didaché, expresa: "Die Didache ist ein deutlicher Beweis dafür, dass das Prophetentum in den Gemeinden ihr Ansehn sinkt, trotzdem eine Persönlichkeit wie Ignatius prophetische Begabung besitzt. Der Verfall hängt einmal mit dem Missbrauch zusammen, den einzelne mit der prophetischen Autorität getrieben haben (Did 11, 8-12); sodann damit, dass der Geltungsbereich der wandernden Propheten gegenüber dem im Wachsen begriffenen Ansehn der sesshaften Funktionäre immer beschränkter wird (Did 13, 1; 15, 1.2)" (Der Hirt des Hermas (Die Apostolischen Väter, 4), Tübingen 1923, p. 539). Cf. Friedrich, Pr. in der alten Kirche, 861s. También influye la creciente autoridad del ministerio ordenado, la incapacidad del profetismo para transmitir la verdad apostólica con propiedad.

243 “Authentische Gegenwartsprophetie konnte sich wegen des überhandnehmens von falschen Propheten, der Schwierigkeit der 'Unterscheidung der Geister' (1 Kor. 12, 10) und der 'Uberflüssigkeit' der Prophetie angesichts der in Jesus als dem Christus erfüllten alttestamentlichen Prophezeiungen kaum halten; ein letzter Aufflackern erlebte die Prophetie im Montanismus" (R. Glei, Prophetie. 1. Antike und Patristik, HWPh, VII, 1473-1475, col. 1474). "Jesus Christus ist zugleich die Erfüllung und das Ende der alten Prophetie; er ist ihre Zusammenfassung und ihre Überbietung. Nach ihm werden keine Propheten mehr im alttestamentlichen Sinne auftreten. Denn an der Stellung der Verheissung ist jetzt die Erfüllung getreten" (Panagopoulos, Die urchristliche Prophetie, 7). Concluía Fascher (op. cit., 223): "Die bescheidene Rolle, welche die christlichen Propheten gespielt haben, erklärt sich wohl daher, dass sie für den inneren Gemeindebetrieb Bedeutung hatten, für den Kampf nach aussen hingegen nicht verwendbar waren. Die Apostel waren ihnen übergeordnet und standen als Sendboten des Kúpıs im Vordergrund des Interesses. Die Polemik gegen die alten griechischen Philosophen, denen man die noch älteren Propheten des A. T. entgegensetzte, die antijüdische These, dass in Christus alle Prophetie ihre Vollendung gefunden haben, verhinderten ohnedies, nach dem Logos-Christus noch Propheten als Autoritäten anzuerkennen. Wie die jüdische und heidnische, so erlosch auch die christliche Prophetie. So hat sich im Kampf gegen Juden, Ketzer und Heiden für die Verklammerung des A. T. und N. T., die Identifizierung des Prophetengottes mit dem Gotte Jesu Christi und die Einheitlichkeit der Gottesoffenbarung durch die Idee des Logos das Werk des 4. Evangelisten als überaus brauchbar erwiesen. Ein Gott und ein Prophet -das war der Kampfruf, mit dem man gegen offenen und versteckten Polytheismus und Polyprophetismus vorging".

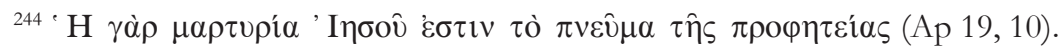

245 “Cette juste remarque (contra una supuesta lucha entre institución y carisma) nous amène à distinguer entre la prophétie constitutive de l'Église (cf. Ephes., 2, 20), qui a joué un rôle décisif pour l'élaboration de la tradition chrétienne, et les dons particuliers de l'Esprit, qui, selon les âges, se présentent sous des formes diverses. Plusieurs passages du Nouveau Testament (va a citar 2 Tm 3, 14s; 1, 13; 2, 2; Jud 5; 2 P 3, 2; $1 \mathrm{P} 1,12$; Jn 15, 26s) manifestent cette conviction que la tradition apostolique fait autorité et qu'on ne saurait ni la modifier, ni lui ajouter quoi que ce soit de substantiel [...] Après Jean de Patmos, l'Apôtre lui-même ou l'un de ses proches disciples, il n'eut plus personne dans l'Église pour revendiquer le droit de parler avec autorité 
au nom du Christ. Désormais, ce sont les 'didascales', clercs ou laïcs, qui exercent l'influence la plus considérable" (Cothenet, Prophétisme, 1335s).

${ }^{246}$ No parece ser así en el caso del autor del Ap, el cual, por lo demás, se dirige a las Iglesias sin nombrar ningún encargado de ellas, a no ser que sus ángeles sean los obispos. Pero la profecía es el testimonio sobre Jesús. "Yet the problem of discerning the true prophet from the false prophet indicates that no prophet was exempt from testing, even though the criteria developed were so vague that they were virtually useless" (Aune, Prophecy, 217).

247 "In respect of self-restraint, as in the matter of evaluation, the Prophets of the Old Testament -with their indisputable authority and sense of compulsion to speak- are not in the same class as New Testament prophets: nevertheless, we cannot deny the name 'prophet' to those to whom Paul gives it: we may note that he himself, rather than the prophets he speaks of, stands more firmly in the tradition of those who declared "Thus says the Lord"' (Hill, op cit., 135s).

${ }^{248}$ La acción de los profetas también está acotada, porque la comunidad (no solo el profeta) tiene el Espíritu y los discierne. "Da im Gegensatz zur christlichen Gemeinde im Judentum der Prophet allein den Geist hat, hat er eine grössere Macht über die Menschen, so dass sie ihm zum Teil blindlings folgen. Auch der christliche Prophet verkündigt mit Vollmacht den Willen Gottes, aber er ist nicht der uneingeschränkte Herr über die andern, sondern er ist der Beurteilung unterworfen. Er ragt nicht über die Gemeinde hinaus, sondern er ist genau so wie die andern ein Glied der Gemeinde" (Friedrich, Pr. im Neuen Testasment, 850s).

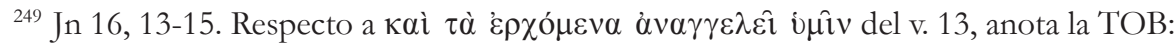
"Il s'agit de dire comment les temps eschatologiques se réaliseront en fonction de ce qui s’accomplit en Jésus” Cf. Jn 14, 26.

${ }^{250}$ Según Boring, "within this milieu, where prophecy was by definition eschatological, early Christianity arose. It was a confirmation of the church's conviction that the Last Times had dawned that prophets emerged within it" (Continuing Voice, 168; cf. Ib., 168-170). "Durch die Prophetie blieben die Fragen nach den Heilratschlüssen Gottes und nach dem Ende und Sinn der Geschichte ständig im Bewusstsein der Gemeinde” (Dautzenberg, Botschaft, 158).

251 "Der Montanismus mit seinen Übertreibungen und Abweichungen im Verhältnis zum korrekt Kirchlichen diskreditierte in hohem Grad den ekstatischen Prophetismus überhaupt in der Kirche" (J. Lindblom, Gesichte und Offenbarungen. Vorstellungen von göttlichen Weisungen und übernatürlichen Erscheinungen im ältesten Christentum, Lund 1968, p. 205).

${ }^{252}$ Según Aune (Prophecy, 194s), el movimiento cristiano en tiempo de Jesús y después en Palestina, fue un movimiento 'milenario'. La comunidad Q, que enfatizaba la profecía, tenía una aspiración milenaria. Los oráculos paganos, empero, no solían ser escatológicos. Con el aumento de los pagano-cristianos se fue produciendo un profundo cambio en la comprensión de la profecía. "Christian prophets and prophecy were in a constant state of change and development from the earliest eschatological prophecy within a millenarian setting of Palestinian Christianity to the final death rattle of prophecy with the rise and rejection of Montanism" (Ib.). 
${ }^{253}$ Profetas que exhortaban, animaban, leían el interior de los corazones, etc., contribuían con su mensaje a la conducción de la Iglesia.

${ }^{254}$ Aunque Aune muestre algunas formas grecorromanas parecidas y posibles influencias de ellas.

${ }^{255}$ Pero expresa Cothenet (Prophétisme, 1335), después de aludir a Ignacio y Policarpo, citando a Campenhausen: "C'est une erreur typiquement moderne, écrit von Campenhausen, de partir de l'opposition supposée entre les groupes ministériels et les groupes charismatiques' (Kirchliches Amt und geistliche Vollmacht, p. 195). L'opposition que l'on décèle au IIe siècle ne proviene pas de ce que les uns se réclament de l'Esprit et les autres de l'institution; ce qui est au centre du débat, c'est la vérité transmise elle-même".

256 "The charisma of prophecy was not consciously driven out of the Church as an inappropriate relic of a past golden age. Instead, the charisma of prophecy was captured by the monarchial episcopate, used in its defense, and left to die an unnoticed death when true episcopal stability rendered it a superfluous tool. But the traces of charisma remained; for the authority of episcopacy lay in its continuity with earliest Christianity, established not only by its faithful adherence to the apostolic norm of Christian Scripture, but also by the continuing presence of the Holy Spirit in the bishop himself" (The Decline of Ecstatic Prophecy in the Early Church, ThSt 37 (1976) 227252, p.251s). Antes había afirmado: "We see in the pastorals, the Didache, Ignatius, Polycarp, Melito, and finally Cyprian a relatively clear trend: the office of bishop at the same time defended the propriety of ecstatic prophecy, used the charisma for its own ends, and rendered it powerless in the hands of others" (Ib., 250). Y respecto al hecho profético de Ignacio en Fil 7, 1s, comentó: “Once Ignatius' oracle 'do nothing without the bishop' became accepted, the prophet's essential authority and freedom was dealt a mortal blow, and prophecy curiously contributed to its own demise" (Ib., 235).

257 "Die frühchristlichen Propheten sind also nicht vom Kanon ausgegrenzt und auch nicht von bischöftlichen Konkurrenten verdrängt worden, sie sind in erter Linie an sich selbst gescheitert, an den Misständen, die sie in den allgemeinen Sog des niedergehenden Wandercharismatikertums rissen und die Hochachtung der Gemeinden in tiefe Skepsis umschlagen liess" (op. cit., 116). "Der Nierdergang der Wanderpropheten ist somit Teil des Verfalls des mediterranen Wandercharismatikertums insgesamt” (Il., 111). Antes había afirmado: “[...] die überwiegende Zahl der Quellen des 2. Jahrhunderts, die auf Propheten zu sprechen kommen, gegen den Missstand der materiellen Bereicherung kämpfen” (Ib., 108).

${ }^{258}$ Pensemos en los mártires, en la explosión del monaquismo, en fundadores de órdenes religiosas, etc.

259 ¿Tiene esta posición simplista algo de resabio de la oposición entre carismáticos y jerarquía ? ¿Dónde están los documentos probatorios al respecto? Ignacio y Policarpo fueron obispos carismáticos. Afirma Aune: "The much discussed problem of the decline of prophecy in early Christianity must be viewed as a social rather than a theological issue. With the institutionalization of Christianity and the rationalization of its authority structures, prophecy became redundant as well as dysfunctional. 
Throughout the entire second century the phenomenon of prophecy was primarily tied to dissenting voices and movements within various phases of Christianity. This does not mean that the prophets became an endangered species primarily because of their increasing association with heretical movements, but it does suggest that the earlier role of the prophets as articulators of the norms, values, and decisions of the invisible head of the church was taken over by the visible figures of the teacher, preacher, theologian, and church leader" (Prophecy, 338). "Prophets and their revelations played an integral role within early Christianity until the beginning of the second century A.D. Thereafter the inevitable forces of institutionalization banished prophets from their roles as leaders and marginalized the revelatory significance of their proclamations. The New Prophecy introduced by Montanus and his followers in the middle of the second century in Asia Minor reveals a total change in the significance of prophecy for early Christianity. Montanism was essentially a charismatic renewal movement within eastern Christianity that had more in common with the millenarian movements of Second Temple Judaism and with the Jesus movement than it had with the kind of prophetic activity which has permeated early Christianity during the second half of the first century. Montanism was labeled a heresy, and thereafter prophets and their revelations were carefully controlled and held in low esteem or even rejected as heretical. In early Christianity, as in Judaism, the gradual decline of prophetic activity is attributable to social rather than theological factors" (Ib., 189).

${ }^{260}$ También influye mi larga participación en la renovación carismática. Durante años viví un sueño de Iglesia en un esplendoroso y bastante numeroso grupo de oración. Pero el tiempo, junto con cierta desidia de parte de la Iglesia jerárquica para acogerlo verdaderamente, ha contribuido a su notable declinar. Pareciera que al clero tampoco le resulta fácil, a la larga, acoger otras comunidades de base. 